\title{
ENVIRONMENTAL SETTING AND IMPLICATIONS ON WATER QUALITY, UPPER COLORADO RIVER BASIN, COLORADO AND UTAH
}

By LORI E. APODACA, NANCY E. DRIVER, VERLIN C. STEPHENS, and NORMAN E. SPAHR

U.S. GEOLOGICAL SURVEY

Water-Resources Investigations Report 95-4263

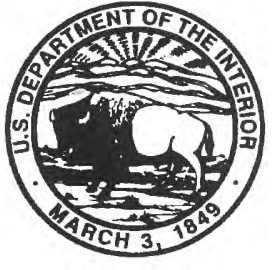




\section{U.S. DEPARTMENT OF THE INTERIOR \\ BRUCE BABBITT, Secretary \\ U.S. GEOLOGICAL SURVEY \\ Gordon P. Eaton, Director}

The use of trade, product, industry, or firm names is for descriptive purposes only and does not imply endorsement by the U.S. Government.

For additional information write to:

District Chief

U.S. Geological Survey

Box 25046, MS 415

Denver Federal Center

Denver, CO 80225
Copies of this report can be purchased from:

U.S. Geological Survey

Earth Science Information Center

Open-File Reports Section

Box 25286, MS 517

Denver Federal Center

Denver, CO 80225 


\section{FOREWORD}

The mission of the U.S. Geological Survey (USGS) is to assess the quantity and quality of the earth resources of the Nation and to provide information that will assist resource managers and policymakers at Federal, State, and local levels in making sound decisions. Assessment of water-quality conditions and trends is an important part of this overall mission.

One of the greatest challenges faced by water-resources scientists is acquiring reliable information that will guide the use and protection of the Nation's water resources. That challenge is being addressed by Federal, State, interstate, and local water-resource agencies and by many academic institutions. These organizations are collecting water-quality data for a host of purposes that include: compliance with permits and water-supply standards; development of remediation plans for a specific contamination problem; operational decisions on industrial, wastewater, or water-supply facilities; and research on factors that affect water quality. An additional need for water-quality information is to provide a basis on which regional and national-level policy decisions can be based. Wise decisions must be based on sound information. As a society we need to know whether certain types of water-quality problems are isolated or ubiquitous, whether there are significant differences in conditions among regions, whether the conditions are changing over time, and why these conditions change from place to place and over time. The information can be used to help determine the efficacy of existing water-quality policies and to help analysts determine the need for and likely consequences of new policies.

To address these needs, the Congress appropriated funds in 1986 for the USGS to begin a pilot program in seven project areas to develop and refine the National Water-Quality Assessment (NAWQA) Program. In 1991, the USGS began full implementation of the program. The NAWQA Program builds upon an existing base of water-quality studies of the USGS, as well as those of other Federal, State, and local agencies. The objectives of the NAWQA Program are to:

-Describe current water-quality conditions for a large part of the Nation's freshwater streams, rivers, and aquifers.

- Describe how water quality is changing over time.

-Improve understanding of the primary natural and human factors that affect water-quality conditions. This information will help support the development and evaluation of management, regulatory, and monitoring decisions by other Federal, State, and local agencies to protect, use, and enhance water resources.

The goals of the NAWQA Program are being achieved through ongoing and proposed investigations of 60 of the Nation's most important river basins and aquifer systems, which are referred to as study units. These study units are distributed throughout the Nation and cover a diversity of hydrogeologic settings. More than two-thirds of the Nation's freshwater use occurs within the 60 study units and more than two-thirds of the people served by public water-supply systems live within their boundaries.

National synthesis of data analysis, based on aggregation of comparable information obtained from the study units, is a major component of the program. This effort focuses on selected water-quality topics using nationally consistent information. Comparative studies will explain differences and similarities in observed water-quality conditions among study areas and will identify changes and trends and their causes. The first topics addressed by the national synthesis are pesticides, nutrients, volatile organic compounds, and aquatic biology. Discussions on these and other water-quality topics will be published in periodic summaries of the quality of the Nation's ground and surface water as the information becomes available.

This report is an element of the comprehensive body of information developed as part of the NAWQA Program. The program depends heavily on the advice, cooperation, and information from many Federal, State, interstate, Tribal, and local agencies and the public. The assistance and suggestions of all are greatly appreciated. 



\section{CONTENTS}

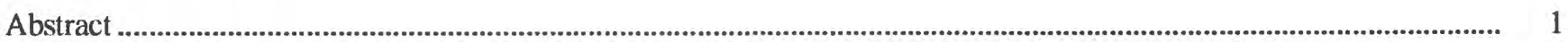

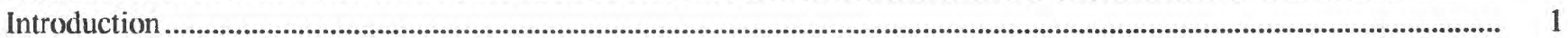

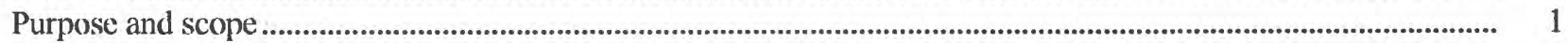

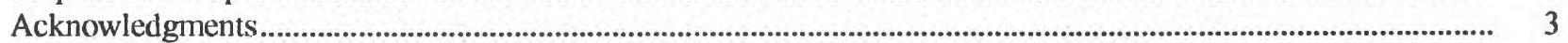

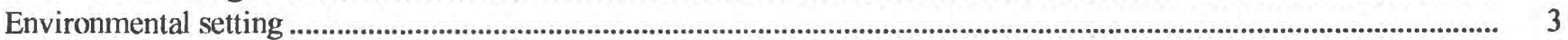

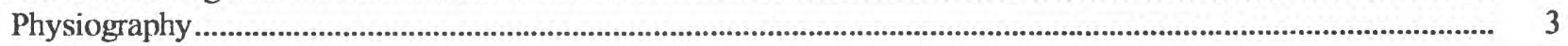

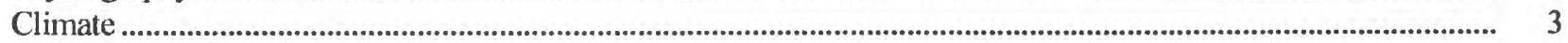

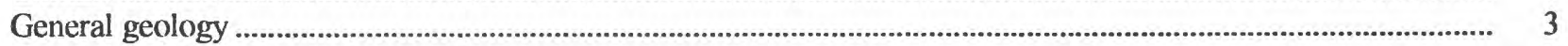

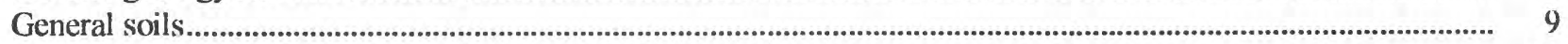

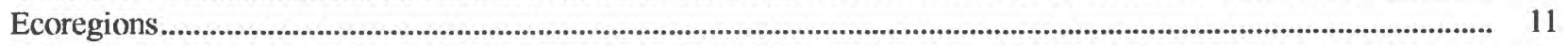

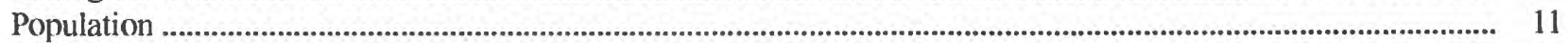

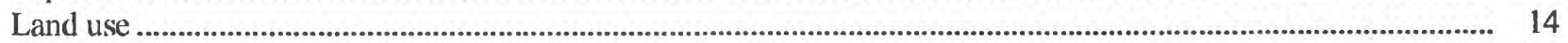

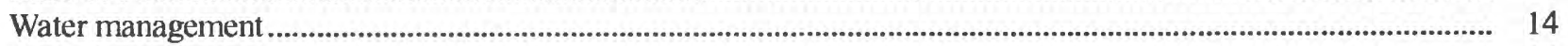

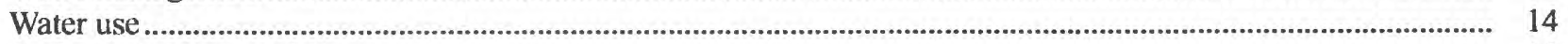

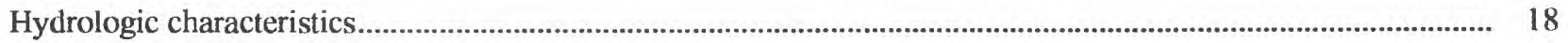

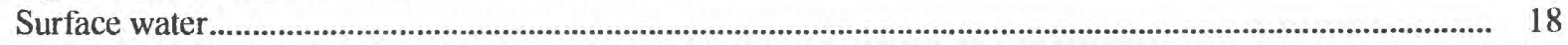

Annual and monthly flow characteristics........................................................................................ 20

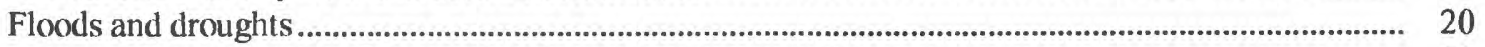

Human effects on streamflow......................................................................................................... 20

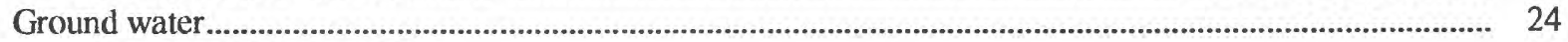

Unconsolidated aquifers................................................................................................................ 24

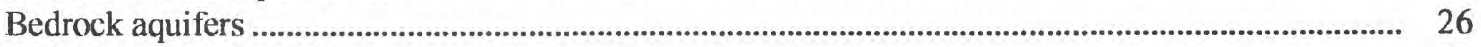

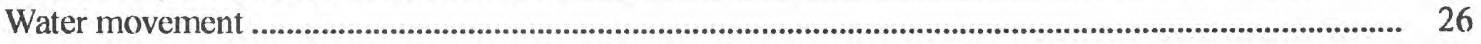

Stream-aquifer relations ...................................................................................................................................... 26

Aquatic biological characteristics .......................................................................................................................... 26

Implications of environmental setting on water quality .................................................................................................. 28

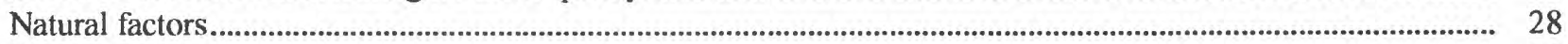

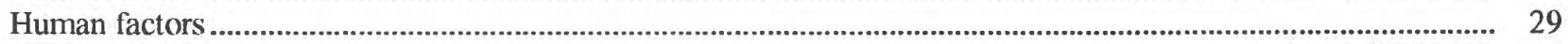

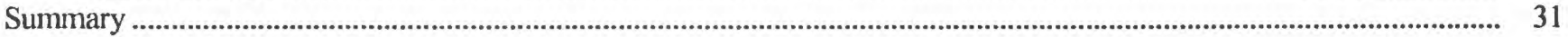

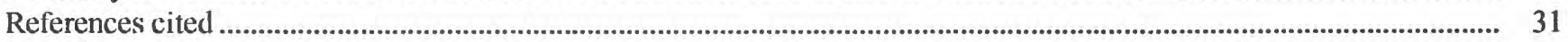

\section{FIGURES}

1-9. Maps showing:

1. Location of the Upper Colorado River Basin study unit, physiographic provinces, major streams, and selected surface-water stations

2. Average annual precipitation (1951-80) in the Upper Colorado River Basin study unit

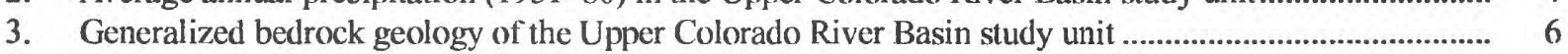

4. Major tectonic features of the Upper Colorado River Basin study unit ................................................... 8

5. Soil associations in the Upper Colorado River Basin study unit.......................................................... 9

6. Ecoregions of the Upper Colorado River Basin study unit .............................................................. 12

7. Population density in the Upper Colorado River Basin study unit...................................................... 13

8. Major land use in the Upper Colorado River Basin study unit................................................................. 15

9. Major interbasin water transfers, water diversions, reservoirs, and municipal discharges in the Upper Colorado River Basin study unit.................................................................................... 16

10-12. Graphs showing:

10. Mean annual streamflow at selected surface-water stations in the Upper Colorado River Basin study unit .

11. Mean monthly streamflow at selected surface-water stations in the Upper Colorado River Basin study unit

12. Streamflow probability of exceedance and nonexceedance at selected surface-water stations in the Upper Colorado River Basin study unit. 


\section{TABLES}

1. Generalized stratigraphic column of the Upper Colorado River Basin study unit .............................................

2. Physical and chemical characteristics of typical soils in the Upper Colorado River Basin study unit.................... 10

3. Major interbasin water transfers, water diversions, reservoirs, and municipal discharges in the Upper Colorado River Basin study unit

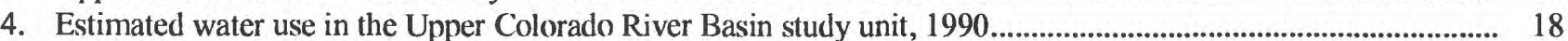

5. Generalized water budget for the Upper Colorado River Basin study unit ...................................................... 19

6. Hydrologic characteristics of selected surface-water stations in the Upper Colorado River Basin study unit......... 19

7. General hydrologic description of selected aquifers in the Upper Colorado River Basin study unit ....................... 25

8. Major aquatic biological taxa in the Southern Rocky Mountains and Colorado Plateau physiographic provinces of the Upper Colorado River Basin study unit

\section{CONVERSION FACTORS, ABBREVIATIONS, AND VERTICAL DATUM}

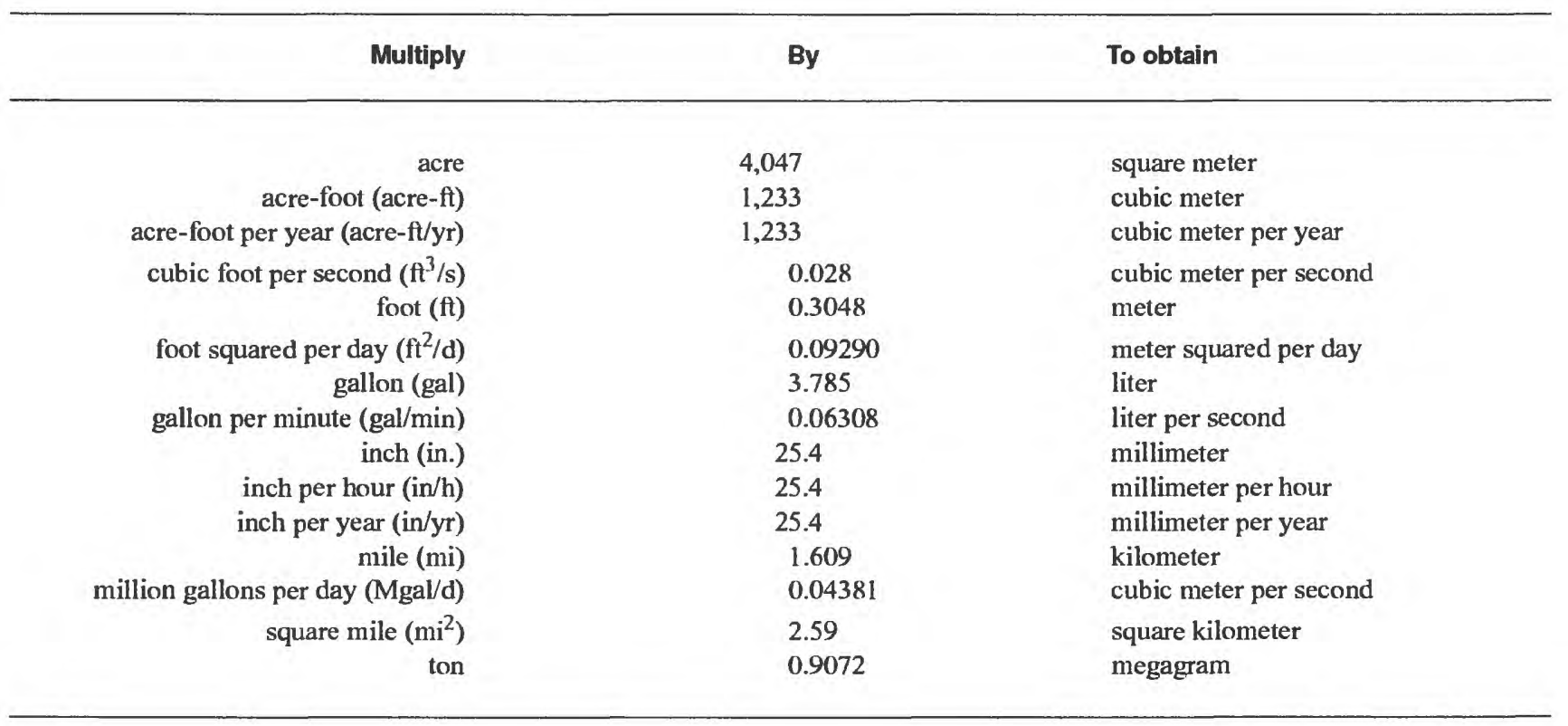

Degree Fahrenheit $\left({ }^{\circ} \mathrm{F}\right)$ may be converted to degree Celsius $\left({ }^{\circ} \mathrm{C}\right)$ by using the following equation:

$$
{ }^{\circ} \mathrm{C}=5 / 9\left({ }^{\circ} \mathrm{F}-32\right) \text {. }
$$

The following abbreviation also is used in this report:

milligram per liter $(\mathrm{mg} / \mathrm{L})$

Sea level: In this report "sea level" refers to the National Geodetic Vertical Datum of 1929 (NGVD of 1929)-a geodetic datum derived from a general adjustment of the first-order level nets of both the United States and Canada, formerly called Sea Level Datum of 1929. 


\title{
Environmental Setting and Implications on Water Quality, Upper Colorado River Basin, Colorado and Utah
}

\author{
By Lori E. Apodaca, Nancy E. Driver, Verlin C. Stephens, and Norman E. Spahr
}

\section{Abstract}

The Upper Colorado River Basin in Colorado and Utah is 1 of 60 study units selected for water-quality assessment as part of the U.S. Geological Survey's National Water-Quality Assessment program, which began full implementation in 1991. Understanding the environmental setting of the Upper Colorado River Basin study unit is important in evaluating water-quality issues in the basin. Natural and human factors that affect water quality in the basin are presented, including an overview of the physiography, climatic conditions, general geology and soils, ecoregions, population, land use, water management and use, hydrologic characteristics, and to the extent possible aquatic biology. These factors have substantial implications on water-quality conditions in the basin. For example, high concentrations of dissolved solids and selenium are present in the natural background water conditions of surface and ground water in parts of the basin. In addition, mining, urban, and agricultural land and water uses result in the presence of certain constituents in the surface and ground water of the basin that can detrimentally affect water quality. The environmental setting of the study unit provides a framework of the basin characteristics, which is important in the design of integrated studies of surface water, ground water, and biology.

\section{INTRODUCTION}

In 1991, the U.S. Geological Survey, U.S. Department of the Interior, began full implementation of the National Water-Quality Assessment (NAWQA) program. The long-term goals of the NAWQA program are to: (1) Describe current waterquality conditions for a large part of the Nation's freshwater streams, rivers, and aquifers; (2) describe how water quality is changing over time; and

(3) improve understanding of the primary natural and human factors that affect water-quality conditions (Leahy and others, 1990). In meeting these goals,
60 study units representing the Nation's most important river basins and aquifers are being investigated. Information obtained from the different study units will help in the management, regulatory, and monitoring decisions by other Federal, State, and local agencies to better protect, use, and enhance water resources. To effectively design and conduct a multidisciplinary water-quality assessment of a large basin, the current environmental setting and implications on water quality need to be determined.

The Upper Colorado River Basin study unit (fig. 1) in Colorado and Utah has a drainage area of about $17,800 \mathrm{mi}^{2}$; all except $100 \mathrm{mi}^{2}$ of this area is in Colorado (Driver, 1994). The Colorado River and its tributaries originate in the mountains of central Colorado and flow about $230 \mathrm{mi}$ southwest into Utah. These mountains form the Continental Divide, which is the eastern and southern boundary of the study unit. The major tributaries to the Colorado River in the study unit are the Blue, Eagle, Roaring Fork, and Gunnison Rivers.

The study unit is predominantly rural and has a population of about 234,000 people (Bureau of Census, 1990), with more than 99 percent of the people residing in Colorado. The largest population center in the basin is the area around Grand Junction, Colo. Tourism is a major year-round activity and accounts for substantial increases in population primarily during the winter and summer (Driver, 1994).

\section{Purpose and Scope}

This report describes environmental characteristics of the Upper Colorado River Basin study unit and the natural and human factors that are considered to affect current (1995) water-quality conditions in the basin. The description of the environmental setting is based on a review of data and reports from Federal, State, and local agencies and industries. For more information on environmental characteristics and water-quality conditions and issues in the study unit, the reader can refer to a bibliography of water-related studies within the Upper Colorado River Basin (Bauch and Apodaca, 1995) or to specific literature cited in this report. 


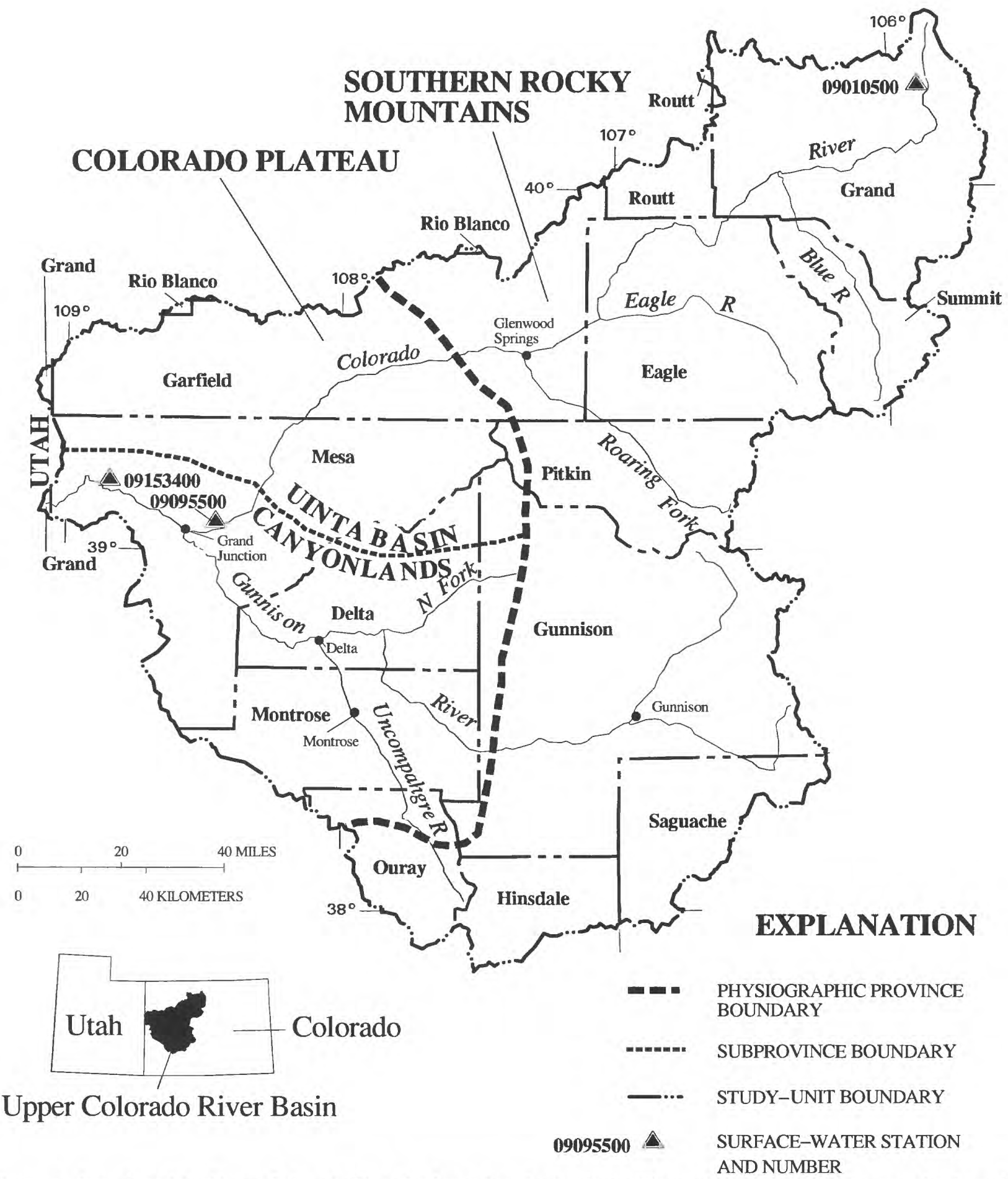

Figure 1. Location of the Upper Colorado River Basin study unit, physiographic provinces, major streams, and selected surface-water stations. 


\section{Acknowledgments}

The authors thank members of the Upper Colorado River Basin Liaison Committee for their cooperation in providing information and data about the basin. We would especially like to thank Leslie Simpson from the Colorado Department of Health and Environment for providing the National Pollution Discharge Elimination System (NPDES) data base; David Dzurochin, Greg Ibarra, and Stephanie Shoebach from the Colorado Department of Natural Resources State Engineer's Office for water diversion information; Robert Crifasi from the Denver Water Board for reviewing the manuscript; and Jim Hokit from the Uncompahgre Valley Water Users Association for water diversion information.

\section{ENVIRONMENTAL SETTING}

The environmental setting of the Upper Colorado River Basin study unit is described on the basis of natural and human factors. Natural factors that affect background water-quality conditions are physiography, climate, geology, and soils. Human factors that affect background water-quality conditions are population, land use, water management, and water use in the basin. Hydrologic and aquatic biological characteristics are affected by natural and human factors.

\section{Physiography}

The study unit is divided almost equally into two physiographic provinces: the Southern Rocky Mountains in the eastern part and the Colorado Plateau in the western part (Hunt, 1974) (fig. 1). The Colorado Plateau has been divided further into the Uinta Basin and the Canyonlands subprovinces on the basis of gcologic features and formations that are in these areas. In the eastern part of the study unit, north-northwesttrending mountains range in altitude from 11,000 to more than 14,000 ft; these mountains are flanked on the west by steeply dipping sedimentary rocks. The Continental Divide marks the eastern and southern boundary of the study unit. In general, the topography in the western part of the study unit generally consists of high plateaus with altitudes ranging from about 5,500 to $8,500 \mathrm{ft}$, bordered by steep cliffs along the valleys. The altitude of the valleys near the Colorado-Utah border is about $4,300 \mathrm{ft}$.

\section{Climate}

Because of large differences in altitude, the climate in the study unit varies substantially from alpine conditions in the east to semiarid in the west. Daily, monthly, and annual average temperatures are highest at the lower altitudes to the west. Mean annual temperatures range from as low as $32.8^{\circ} \mathrm{F}$ in Gunnison County near the Continental Divide to as high as $54.1^{\circ} \mathrm{F}$ near Grand Junction (Benci and McKee, 1977). Temperatures in the study unit are coldest during January and are warmest during July and August.

Precipitation in the basin ranges from more than $40 \mathrm{in} / \mathrm{yr}$ in the eastern mountainous regions to less than $10 \mathrm{in} / \mathrm{yr}$ in the western regions. Mountain areas receive most of their precipitation during the winter when average seasonal accumulations of snow can exceed 100 in. In the Grand Junction area, the largest amount of precipitation occurs during August as a result of weather patterns that produce late-afternoon thunderstorms (Chaney and others, 1987). The areas having the most precipitation are at the higher altitudes generally in the eastern and southern parts of the study unit (fig. 2); precipitation decreases toward the lower altitudes in the western part of the study unit.

\section{General Geology}

Bedrock geology for the study unit is described in table 1 and shown in figure 3; the geology varies substantially and consists of crystalline rocks of Precambrian age, stratified sedimentary rocks, and alluvial deposits. The following paragraphs give a brief description of geologic units from oldest to youngest that are most prevalent or have a substantial implication on water quality.

Within the central parts of the uplifted mountainous areas in the Upper Colorado River Basin, Precambrian metamorphic schists and gneisses that have been intruded by granitic igneous rocks are exposed. The Precambrian rocks are overlain by sedimentary rocks of Paleozoic, Mesozoic, and Cenozoic age. Rocks of Cambrian to Mississippian age primarily are composed of carbonates (dolomite and limestone) with interbedded sandstones. Rocks of late Paleozoic age consist of interbedded shales, sandstones, limestones, and local deposits of salt and gypsum. Rocks of early to middle Mesozoic age consist of alternating sandstones and shale units. Some of the rocks of Jurassic and Cretaceous age that are of importance in the study unit are divided as follows: Entrada Sandstone; Morrison Formation, consisting of varicolored siltstone and mudstone with beds of sandstone and limestone; 


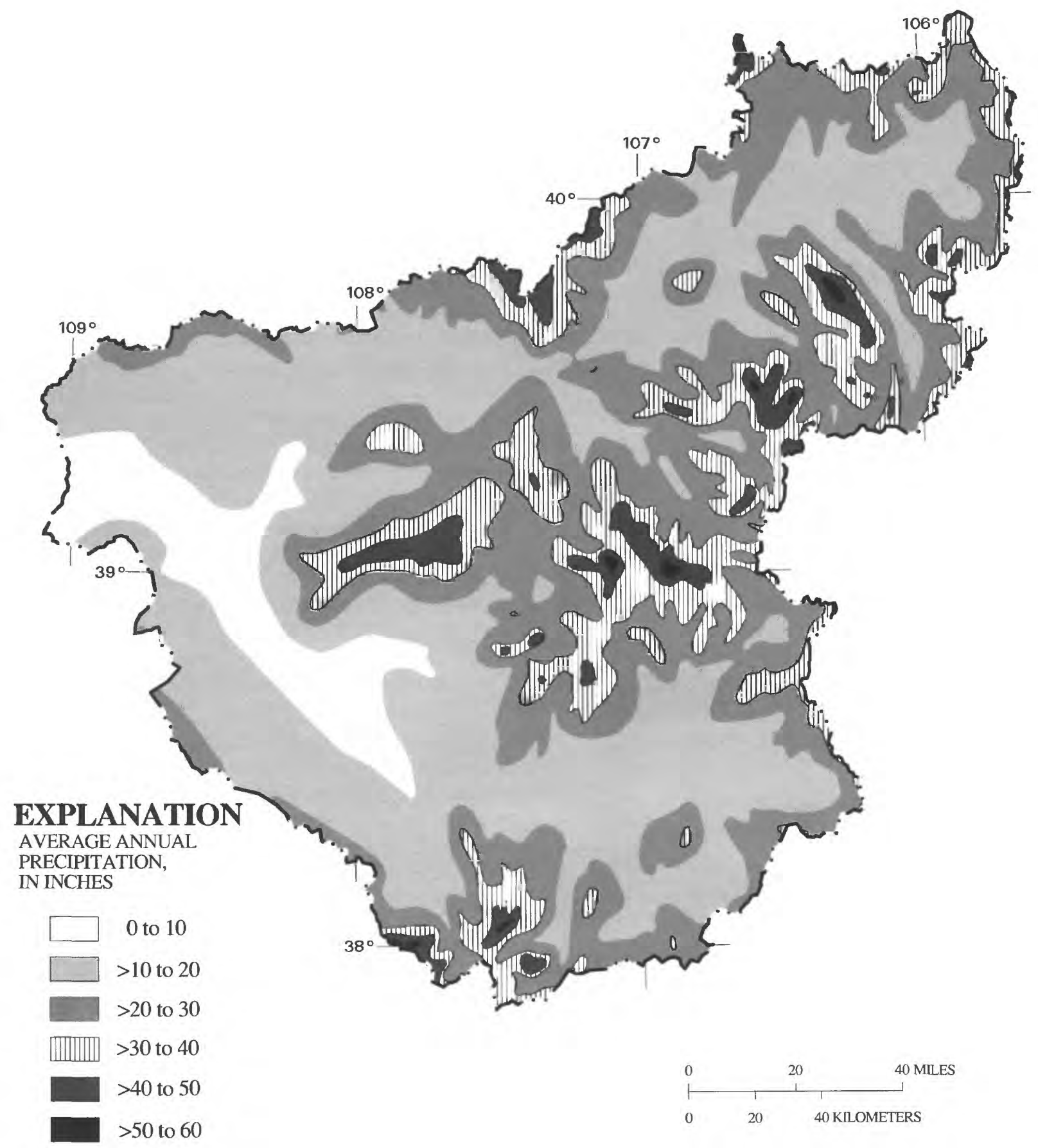

Figure 2. Average annual precipitation (1951-80) in the Upper Colorado River Basin study unit (Colorado Climate Center, 1984). 
Table 1. Generalized stratigraphic column of the Upper Colorado River Basin study unit

[---, no data; Fm, formation; Ss, sandstone; Grp, group; Sh, shale; Ls, limestone. Parentheses indicate geologic units associated with the specific formation or group. Modified from Cashion, 1973; Pearl, 1974; Tweto, 1976; 1979; 1980; Tweto and others, 1978.]

\begin{tabular}{|c|c|c|c|c|c|}
\hline Period & Epoch & Stratigraphic unit & Principal lithology & $\begin{array}{l}\text { Thickness } \\
\text { (feet) }\end{array}$ & $\begin{array}{l}\text { Map } \\
\text { symbol } \\
\text { used in } \\
\text { figure } 3\end{array}$ \\
\hline \multirow[t]{2}{*}{ Quaternary } & $\begin{array}{l}\text { Holocene and } \\
\text { Pleistocene }\end{array}$ & Valley-fill deposits & $\begin{array}{l}\text { Clay, sand, gravel, boulders, and glacial } \\
\text { debris }\end{array}$ & $20-140$ & $\begin{array}{l}\text { Not } \\
\text { mapped }\end{array}$ \\
\hline & & $\begin{array}{l}\text { Colluvium, landslide } \\
\text { debris, glacial moraines, } \\
\text { terrace deposits }\end{array}$ & Silt, clay, sand, gravel, and debris piles & $10-100$ & $\begin{array}{l}\text { Not } \\
\text { mapped }\end{array}$ \\
\hline $\begin{array}{l}\text { Quaternary } \\
\text { and Tertiary }\end{array}$ & & Volcanic rocks & $\begin{array}{l}\text { Lava flows, breccias, tuff, and related } \\
\text { materials }\end{array}$ & -- & QTuv \\
\hline \multirow[t]{5}{*}{ Tertiary } & $\begin{array}{l}\text { Miocene and } \\
\text { Oligocene }\end{array}$ & Browns Park Fm & $\begin{array}{l}\text { Fine-grained grayish sandstone, gravel, } \\
\text { cobbles, chert, fresh water limestone, } \\
\text { and a conglomerate at the base }\end{array}$ & As thick as 1,800 & $\mathrm{Tu}$ \\
\hline & & Troublesome Fm & $\begin{array}{l}\text { Chiefly siltstone; contains beds of volcanic } \\
\text { ash and some sandstone and conglomerate }\end{array}$ & As thick as 1,500 & $\mathrm{Tu}$ \\
\hline & Eocene & Uinta Fm & $\begin{array}{l}\text { Sandstone and siltstone in the Piceance } \\
\text { Basin }\end{array}$ & As thick as 1,000 & $\mathrm{Tl}$ \\
\hline & & Green River Fm & $\begin{array}{l}\text { Intertonguing lenses of siltstone, marlstone, } \\
\text { sandstone, limestone, and shale }\end{array}$ & As thick as 3,500 & Tl \\
\hline & $\begin{array}{c}\text { Eocene and } \\
\text { Paleocene }\end{array}$ & Wasatch Fm & $\begin{array}{l}\text { Clay, shale, and lenses of sandstone, } \\
\text { limestone, and conglomerate }\end{array}$ & $300-5,000$ & $\mathrm{Tl}$ \\
\hline \multirow[t]{2}{*}{$\begin{array}{r}\text { Tertiary and } \\
\text { Cretaceous }\end{array}$} & $\begin{array}{l}\text { Paleocene and } \\
\text { Late Cretaceous }\end{array}$ & Middle Park Fm & $\begin{array}{l}\text { Sandstone, shale, conglomerate, and } \\
\text { breccia }\end{array}$ & $2,500-5,000$ & TK1 \\
\hline & & $\begin{array}{l}\text { Volcanic rocks of the } \\
\text { Laramide Orogeny }\end{array}$ & $\begin{array}{l}\text { Intrusive rocks - mainly intermediate to } \\
\text { felsic in composition, some mafic }\end{array}$ & -- & TKv \\
\hline \multirow[t]{5}{*}{ Cretaceous } & Late & $\begin{array}{l}\text { Mesaverde Grp } \\
\text { (Price River Fm) }\end{array}$ & $\begin{array}{l}\text { Mudstone, shale, coal, and varicolored, } \\
\text { crossbedded sandstone }\end{array}$ & $1,500-5,300$ & Kul \\
\hline & & Mancos Sh & $\begin{array}{l}\text { Dark shale and calcareous shale with } \\
\text { interbedded sandstone }\end{array}$ & As thick as 4,000 & $\mathrm{Ku} 2$ \\
\hline & & Pierre Sh & $\begin{array}{l}\text { Dark shale and sandy shale with local } \\
\text { stringers of sandstone }\end{array}$ & $200-4,000$ & Ku2 \\
\hline & & $\begin{array}{l}\text { Colorado Grp } \\
\text { (Niobrara Fm and } \\
\text { Benton Sh) }\end{array}$ & $\begin{array}{l}\text { Calcareous shale and thin-bedded limestone } \\
\text { interbedded with shale, dark fissile shale } \\
\text { with bentonitic seams, and sandstone }\end{array}$ & $200-700$ & Ku2 \\
\hline & Early & $\begin{array}{l}\text { Dakota Ss, } \\
\text { Burro Canyon Fm }\end{array}$ & $\begin{array}{l}\text { Light-colored sandstone, mostly cross- } \\
\text { bedded, dark shale, and thin beds of coal }\end{array}$ & As thick as 300 & $\mathrm{Kl}$ \\
\hline \multirow[t]{3}{*}{ Jurassic } & Late & $\begin{array}{l}\text { Morrison Fm } \\
\text { (Brushy Basin Member) }\end{array}$ & $\begin{array}{l}\text { Varicolored siltstone and mudstone with } \\
\text { beds of sandstone and limestone }\end{array}$ & $250-600$ & $\mathrm{~J}$ \\
\hline & Middle & Entrada Ss & Fine-grained sandstone, mostly crossbedded & $50-200$ & $\mathbf{J}$ \\
\hline & Early & $\begin{array}{l}\text { Glen Canyon Fm } \\
\text { or Grp, Wingate Ss }\end{array}$ & $\begin{array}{l}\text { Sandstone, lenses of limestone, varicolored } \\
\text { siltstone, and mudstone }\end{array}$ & As thick as 500 & k \\
\hline Triassic & Late & Chinle Fm & Red siltstone, sandstone, and limestone & $80-120$ & 下 \\
\hline $\begin{array}{l}\text { Permian and } \\
\text { Pennsylvanian }\end{array}$ & & $\begin{array}{l}\text { Maroon Fm, Belden Fm, } \\
\text { Eagle Valley Fm }\end{array}$ & $\begin{array}{l}\text { Dolomite, limestone, quartzite, sandstone, } \\
\text { conglomerate, shale, and chert }\end{array}$ & As thick as 13,000 & PIP \\
\hline Mississippian & & Leadville Ls & Limestone, dolomite, sandstone, and chert & $50-200$ & MDO \\
\hline $\begin{array}{l}\text { Devonian, } \\
\text { Ordovician, and } \\
\text { Cambrian }\end{array}$ & & $\begin{array}{l}\text { Mississippian rocks } \\
\text { including Chaffee Grp } \\
\text { and Manitou Fm }\end{array}$ & Dolomite, limestone, and quartzite & As thick as 2,500 & MDO \\
\hline Precambrian & & & Granite, schist, gneiss, and pegmatite dikes & -- & $\mathrm{p} €$ \\
\hline
\end{tabular}




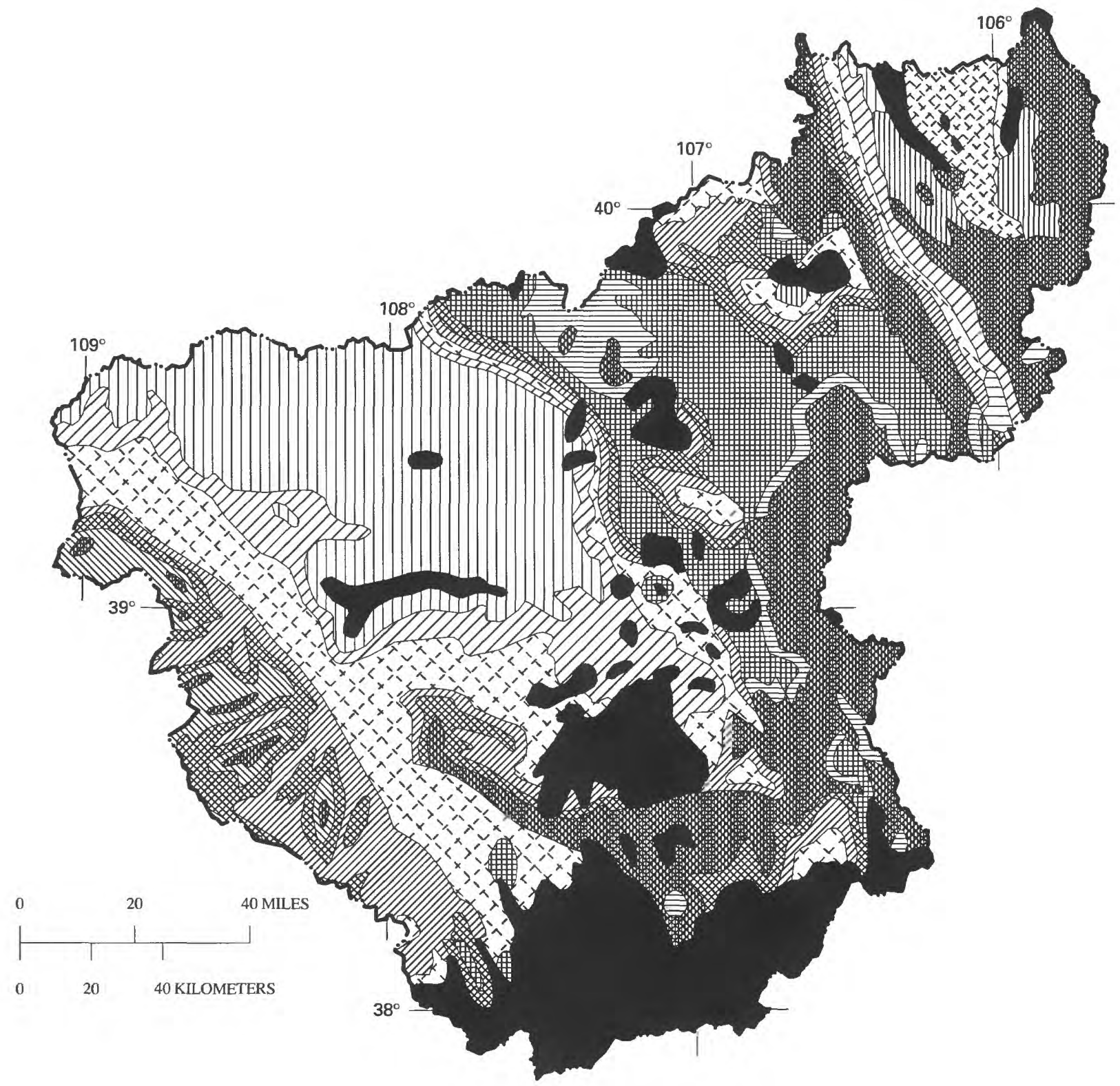

Figure 3. Generalized bedrock geology of the Upper Colorado River Basin study unit (modified from Schruben and others, 1974). 


\title{
EXPLANATION
}

\author{
QUATERNARY and TERTIARY (QTuv)- Volcanic rocks \\ |IIIII] TERTIARY (Tu)- (Browns Park and Troublesome Formations) \\ IIII TERTIARY (Tl)- Uinta, Green River, and Wasatch Formations

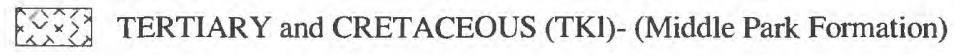 \\ TERTIARY and CRETACEOUS (TKv)- Laramide intrusive rocks \\ DIA UPPER CRETACEOUS (Kul)- Mesaverde Group \\ $\left[x_{x}\right]$ UPPER CRETACEOUS (Ku2)- Mancos Shale, Pierre Shale, and (Colorado Group) \\ LOWER CRETACEOUS (K1)- Dakota Sandstone and Burro Canyon Formation \\ JURASSIC (J)- Morrison Formation and Entrada Sandstone \\ LOWER JURASSIC and UPPER TRIASSIC ( $(\mathrm{k})$ - Glen Canyon Group, Wingate \\ Sandstone, Chinle Formation, (Chinle Formation) \\ PERMIAN and PENNSYLVANIAN (PIP)- (Maroon, Belden, and Eagle Valley \\ Formations) \\ MISSISSIPPIAN, DEVONIAN, ORDOVICIAN, and CAMBRIAN ROCKS \\ (MDOE)- (Includes Leadville Limestone) \\ PRECAMBRIAN (p€)- Igneous and metamorphic rocks \\ NOTE-- STRATIGRAPHIC UNITS IN PARENTHESES DENOTE UNITS \\ LOCATED IN THE SOUTHERN ROCKY MOUNTAINS AREA OF THE \\ BASIN
}

Figure 3. Generalized bedrock geology of the Upper Colorado River Basin study unit (modified from Schruben and others, 1974)-Continued.

Dakota Sandstone composed of sandstones and shales; Mancos Shale; and Mesaverde Group, consisting of sandstone, shale, and coal. The Green River Formation of Tertiary age consists of siltstones, marlstones, sandstones, limestones, and shales. Rocks of Tertiary and Quaternary age are present in the central parts of the subbasins and consist of predominantly continental sandstones, shales, coals, and locally abundant evaporite minerals. Tertiary volcanic rocks exposed in the study unit partially overlay or intrude many of the rocks described above.

The highly variable geologic units of the study unit can be grouped together by the tectonic features present in the basin (fig. 4). These tectonic features represent variations in geology, which also reflect the differences in topography and climate in the study unit. The major tectonic features in the basin include the Gunnison Uplift, Sawatch Uplift, Middle Park Range, Sierra Madre Park Range, White River Uplift, Uncompahgre Uplift, and Piceance Structural Basin, which is considered the western extension of the Uinta Basin (Taylor and others, 1986).

Geology is similar among the Gunnison Uplift, Sawatch Uplift, Middle Park Range, and Sierra Madre Park Range. In this area of the Southern Rocky Mountains province, rocks of gneiss, schists, and granites of Precambrian age crop out and have been intruded by volcanic rocks. This area has been called the Colorado 


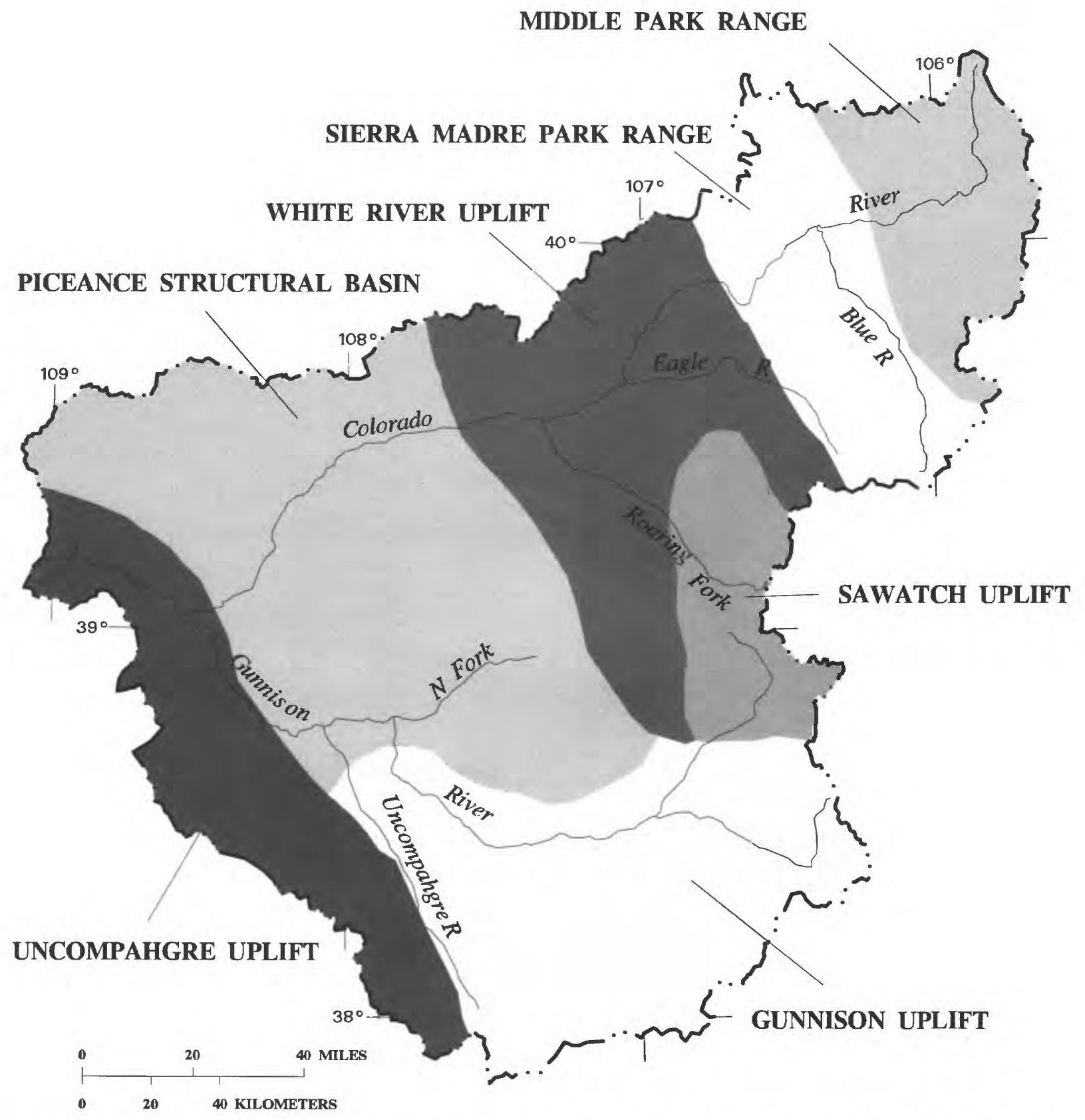

Figure 4. Major tectonic features of the Upper Colorado River Basin study unit (modified from Taylor and others, 1986). 
Mineral Belt because of the high concentration of mineral deposits that occur along a belt following the Continental Divide (Romberger, 1980). In the White River Uplift, the geology consists of carbonate rocks of Pennsylvanian and Permian age, which include the Leadville Limestone and Eagle Valley Formation containing evaporative sequences. Many thermal mineral springs are present throughout the White River Uplift.

The Uncompahgre Uplift, which is west of the Gunnison and Uncompahgre Rivers, consists of sedimentary rocks of Jurassic and Cretaceous age overlying igneous and metamorphic rocks of Precambrian age. Sedimentary rocks of Jurassic and Cretaceous age that crop out include the Entrada Sandstone, Morrison Formation, and Dakota Sandstone. In the southeastern part of the Uncompahgre Uplift, metallic mineral deposits are associated with volcanic rocks of Tertiary age.
In the western part of the study unit, the Piceance Structural Basin is composed of rocks of Cretaceous and Tertiary age such as the Mancos Shale, Mesaverde Group, and Green River Formation. The Cretaceous rocks form the outer edges of this tectonic basin, and the Tertiary rocks are located in the upland areas of this basin.

\section{General Soils}

There are six soil associations in the study unit (fig. 5); a brief description of the general physical and chemical characteristics of each soil association is listed in table 2. Two soil associations are in the mountainous areas of the basin, and the other four soil associations are in areas that include mountainsides, uplands, flood plains, alluvial valley floors, and alluvial

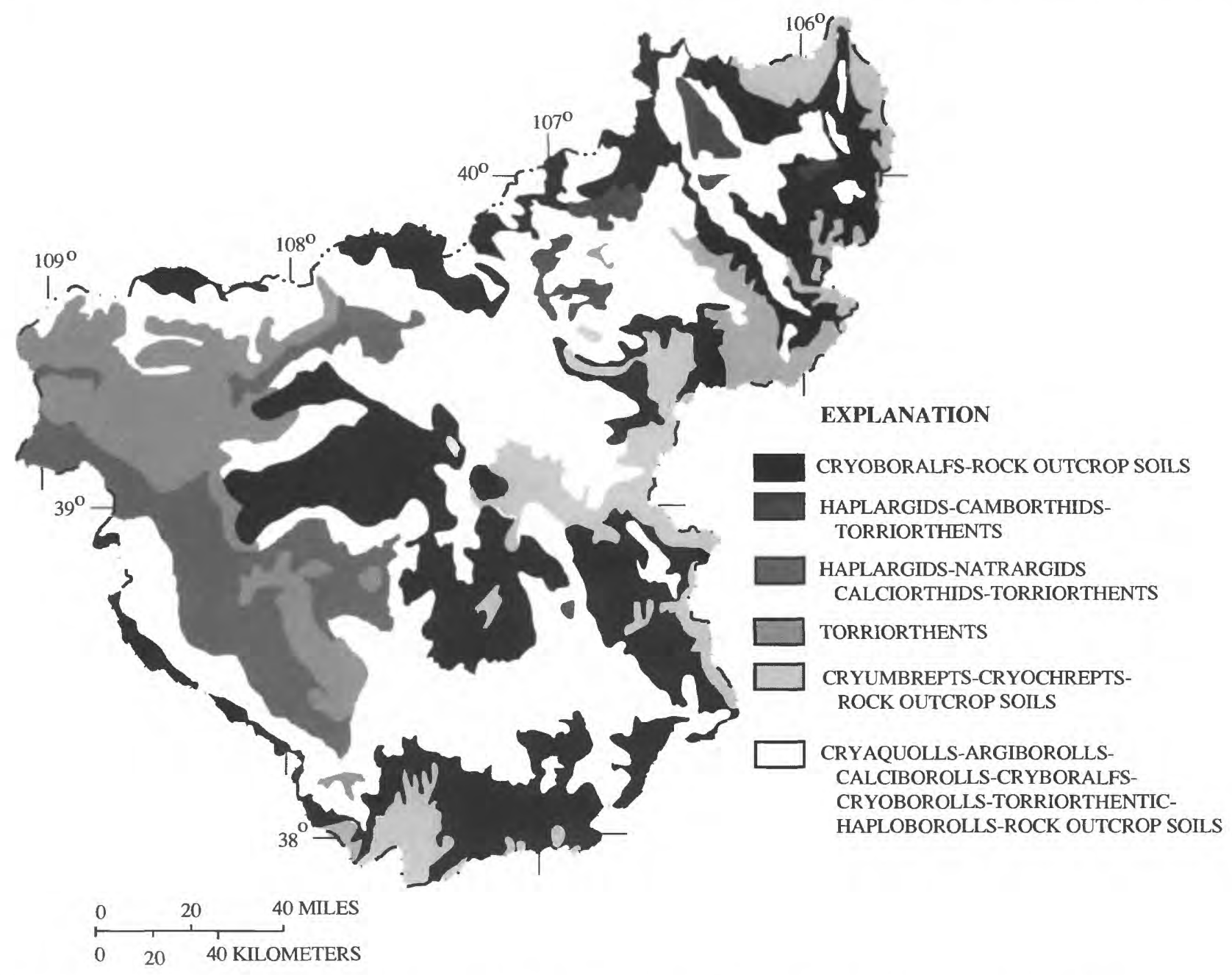

Figure 5. Soil associations in the Upper Colorado River Basin study unit (modified from Heil and others, 1977). 
Table 2. Physical and chemical characteristics of typical soils in the Upper Colorado River Basin study unit

[in., inches; in/h, inches per hour; >, greater than; <, less than. Modified from Heil and others, 1977; Spears and Kleven, 1978; Chaney and others, 1987; Dennehy and others, 1993.]

\begin{tabular}{|c|c|c|c|c|}
\hline Soil association & Subgroup & Description & $\begin{array}{l}\text { Depth to } \\
\text { bedrock } \\
\text { (in.) }\end{array}$ & $\begin{array}{l}\text { Permeability } \\
\text { (in/h) }\end{array}$ \\
\hline \multirow[t]{2}{*}{$\begin{array}{l}\text { Cryoboralfs- } \\
\text { rock outcrop soils }\end{array}$} & $\begin{array}{l}\text { Typic Cryoboralfs, } \\
\text { rock outcrop }\end{array}$ & $\begin{array}{l}\text { Sandy loam to gravely sandy } \\
\text { loam and clayey }\end{array}$ & $20 \rightarrow 60$ & $0.6-2.0$ \\
\hline & Typic Cryoboralfs & Loamy soils & $20 \rightarrow 60$ & $0.6-2.0$ \\
\hline \multirow[t]{2}{*}{$\begin{array}{l}\text { Haplargids-Camborthids- } \\
\text { Torriorthents }\end{array}$} & $\begin{array}{l}\text { Borollic Haplargids, } \\
\text { Ustic Torriorthents }\end{array}$ & Loamy soils & $<20 \rightarrow 60$ & $0.6-2.0$ \\
\hline & Borollic Vertic Camborthids & Clayey soils & $20-40$ & $0.06-2.0$ \\
\hline \multirow{6}{*}{$\begin{array}{l}\text { Haplargids-Natrargids- } \\
\text { Calciorthids-Torriorthents }\end{array}$} & Typic Haplargids & Loamy soils & $>60$ & $0.6-2.0$ \\
\hline & Ustollic Haplargids & Loamy soils & $>60$ & $0.6-20.0$ \\
\hline & Ustollic Haplargids, rock outcrop & Loamy soils & $20 \rightarrow 60$ & $0.6-20.0$ \\
\hline & $\begin{array}{l}\text { Ustollic Haplargids, } \\
\text { Ustic Torriorthents }\end{array}$ & Loamy silty soils & $20>60$ & $0.06-2.0$ \\
\hline & $\begin{array}{l}\text { Ustollic Natrargids, } \\
\text { Ustollic Haplargids }\end{array}$ & $\begin{array}{l}\text { Loamy calcareous soils, } \\
\text { loamy soils with clay }\end{array}$ & $>60$ & $0.06-2.0$ \\
\hline & $\begin{array}{l}\text { Typic Calciorthids, } \\
\text { Ustic Torriorthents }\end{array}$ & Loamy calcareous soils & $20 \rightarrow 60$ & $0.6-2.0$ \\
\hline \multirow[t]{3}{*}{ Torriorthents } & Typic Torrifluvents & Silty clay and silt loam soils & $>60$ & $0.06-2.0$ \\
\hline & Typic Torriorthents & Clayey soils & $<20$ & $0.06-0.20$ \\
\hline & Listic Ustic Torriorthents & $\begin{array}{l}\text { Stony loam, sandy loam, and } \\
\text { gravely loam soils }\end{array}$ & $<20$ & $0.6-2.0$ \\
\hline $\begin{array}{l}\text { Cryumbrepts-Cryochrepts- } \\
\text { rock outcrop soils }\end{array}$ & $\begin{array}{l}\text { Pergelic Cryumbrepts, Pergelic } \\
\text { Cryochrepts, rock outcrop }\end{array}$ & Sandy loams & $20 \rightarrow 40$ & $0.6-6.0$ \\
\hline \multirow{10}{*}{$\begin{array}{l}\text { Cryaquolls-Argiborolls- } \\
\text { Calciborolls-Cryboralfs- } \\
\text { Cryoborolls-Torriorthentic- } \\
\text { Haploborolls-rock outcrop soils }\end{array}$} & $\begin{array}{l}\text { Typic, Argic, and } \\
\text { Cumulic Cryaquolls }\end{array}$ & $\begin{array}{l}\text { Clay loam to gravely, sandy } \\
\text { loam to sand, and gravel }\end{array}$ & $>60$ & $0.2-0.6$ \\
\hline & Aridic Argiborolls, rock outcrop & Loamy soils & $20 \rightarrow 60$ & $0.6-20$ \\
\hline & $\begin{array}{l}\text { Aridic Arbigorolls, } \\
\text { Aridic Haploborolls }\end{array}$ & Clayey soils & $20-60$ & $0.06-0.20$ \\
\hline & Aridic Calciborolls & Loamy soils & $20 \rightarrow 60$ & $0.6-20$ \\
\hline & Typic Cryoborolls, rock outcrop & Loamy soils & $20 \rightarrow 60$ & $0.6-2.0$ \\
\hline & $\begin{array}{l}\text { Typic Cryoborolls, } \\
\text { Typic Cryboralfs }\end{array}$ & Loamy and clayey soils & $20 \rightarrow 60$ & Variable \\
\hline & $\begin{array}{l}\text { Typic Cryoborolls, } \\
\text { Typic Cryorthents }\end{array}$ & Clayey soils & $>16$ & $0.06-0.6$ \\
\hline & Argic and Typic Cryborolls & $\begin{array}{l}\text { Loamy or clayey over } \\
\text { loamy textures }\end{array}$ & $20 \rightarrow 60$ & 0.26 .0 \\
\hline & $\begin{array}{l}\text { Aridic and Torriorthentic } \\
\text { Haploborolls, Aridic Argiborolls }\end{array}$ & Loamy and clayey soils & $20 \rightarrow 60$ & $0.06-2.0$ \\
\hline & Lithic Haploborolls, rock outcrop & Rock outcrop & $20 \rightarrow 60$ & $0.6-20$ \\
\hline
\end{tabular}


fans. Most soils in the study unit are deep, loamy, well-drained soils that are alkaline (Heil and others, 1977).

Soils in the mountainous regions are (1) Cryoboralfs-rock outcrop soils, which are light-colored, well-drained soils that formed from weathering of a variety of crystalline and sedimentary rocks and (2) Cryumbrepts-Cryochrepts-rock outcrop soils, which are dark- to light-colored, well-drained soils in the alpine areas straddling the Continental Divide (table 2) (Heil and others, 1977). Soils in the highest mountainous areas generally are medium to very strongly acidic.

In the nonmountainous areas, the most widely distributed soil association is the CryaquollsArgiborolls-Calciborolls-Cryboralfs-CryoborollsTorriorthentic-Haploborolls-rock outcrop soils, which generally are dark-colored, well-drained, moderately deep to deep soils. The Haplargids-CamborthidsTorriorthents association, which ranges in depth from shallow to deep, has light-colored, well-drained soil, and has formed from weathering of in-place or locally transported sandstones and shales. The HaplargidsNatrargids-Calciorthids-Torriorthents association is deep, light-colored, well-drained soil formed from the weathering of sedimentary rocks and from eolian material. The soil association present at the lower altitudes is the Torriorthents, which has depths ranging from shallow to deep and is a light-colored, well-drained soil that formed from locally weathered sedimentary rocks such as shales and sandstones. Soils in the nonmountainous areas generally are alkaline in nature.

\section{Ecoregions}

Ecological regions (ecoregions) have been established to characterize homogeneous areas on the basis of landscape features such as vegetation, soils, geology, physiography, and land use (Gallant and others, 1989). The study unit has been subdivided into five ecoregions: high-altitude tundra; low- to highaltitude forests; low- to middle-altitude semidesert shrublands; semidesert shrublands and wooded uplands; and salt deserts (fig. 6). The distribution of vegetation is determined primarily by mineral availability from soils and geologic materials and by amount of precipitation (Chaney and others, 1987).

High-altitude tundra is characterized by a cold, humid to arid climate with vegetation above treeline containing low-growth shrubs, cushion plants, and forbs. Along the forest-tundra interface, there are sparse stands of Englemann spruce, subalpine fir, Limber pine, and Bristlecone pine. The middle- to high-altitude forests consist of Englemann spruce and subalpine fir; some areas are locally dominated by aspen. These forests vary from cool humid to warm dry climates depending on the altitude. In the low- to middle-altitude forests, vegetation consists of aspen, Douglas fir, Ponderosa pine, Gambel oak, and Piñon pinejuniper woodlands.

Low- to middle-altitude semidesert shrublands have a semiarid climate with vegetation consisting of greasewood, four-winged saltbrush, shadscale, and sagebrush often interspersed with grasses. Semidesert shrublands and wooded uplands are in a semiarid to arid climate. Sagebrush, rabbitbrush, and grasses grow in the semidesert shrublands. In the wooded uplands, vegetation consists of juniper and Piñon pine, grasses, and sagebrush. Salt deserts are arid and have vegetation consisting of saltbrush, greasewood, rabbitbrush, horsebrush, and desert grasses. In the ecoregions classified as salt deserts and semidesert shrublands, nonnative vegetation grows as a result of agricultural activities in the area. Irrigated crops include barley, corn, fruit, hay, oats, vegetables, and wheat (Chaney and others, 1987).

\section{Population}

The 1990 population in the largely rural Upper Colorado River Basin was about 234,000, less than 10 percent of the total population of the State of Colorado (fig. 7) (Bureau of Census, 1990). The largest population center in the study unit is Grand Junction $(30,209)$, which is located at the confluence of the Colorado and Gunnison Rivers. Some other principal cities in the area include Delta $(3,952)$, Glenwood Springs $(6,841)$, Gunnison $(4,762)$, and Montrose $(9,306)$ (Bureau of Census, 1992). The larger cities in the basin are located predominantly near agricultural lands or in mountain recreational communities. Population of many counties in the basin increased about 5 percent from 1990 to 1992. Eagle and Summit Counties had the largest increases, of about 12 and 13 percent, respectively. Population totals are projected to increase for some of the counties (Delta, Eagle, Gunnison, Montrose, and Summit) in the basin by more than 20 percent in the year 2000 (Colorado Division of Local Governments, 1994). Population in the basin for the year 2000 would be expected to exceed 300,000 . 


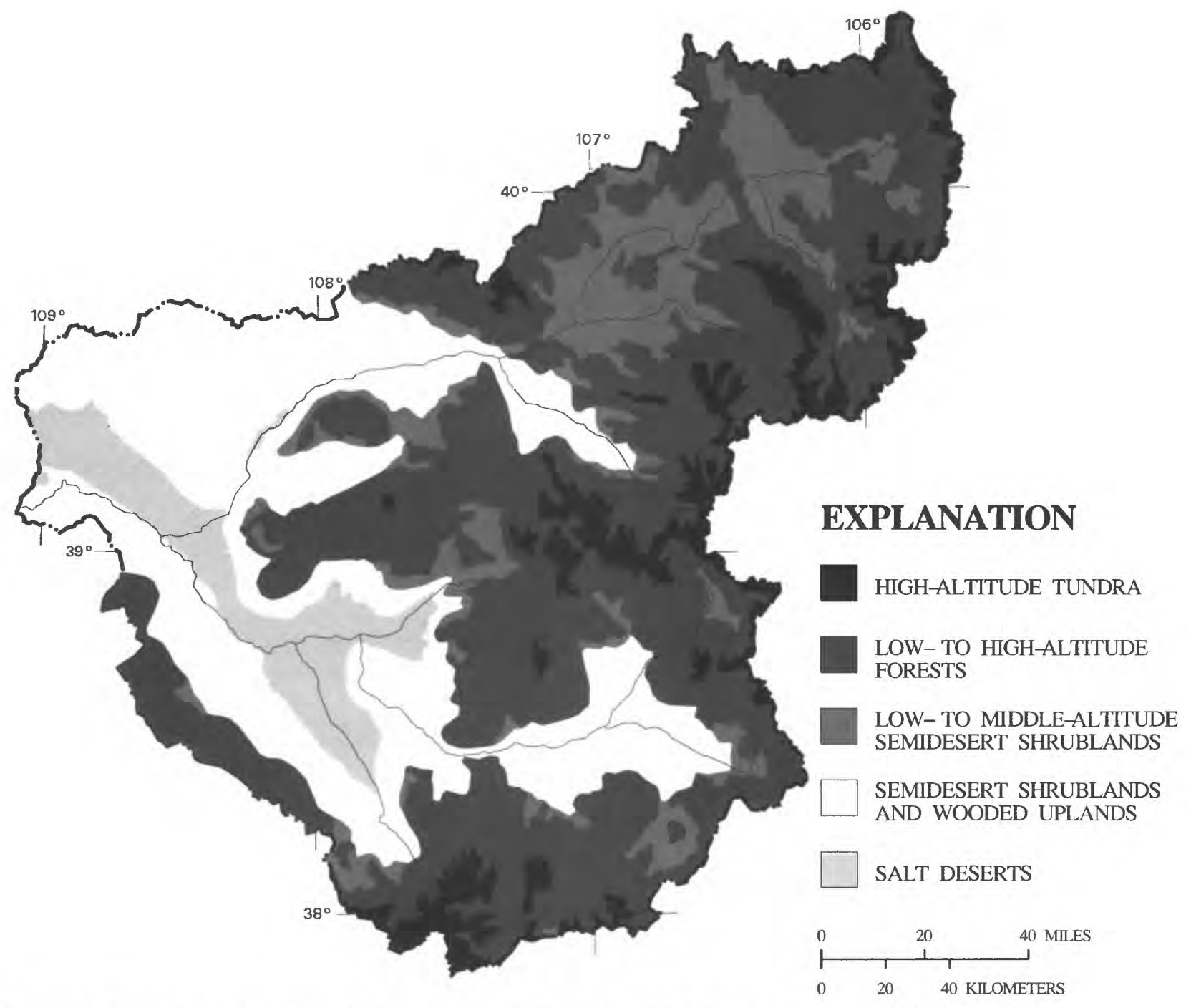

Figure 6. Ecoregions of the Upper Colorado River Basin study unit (Gallant and others, 1989). 


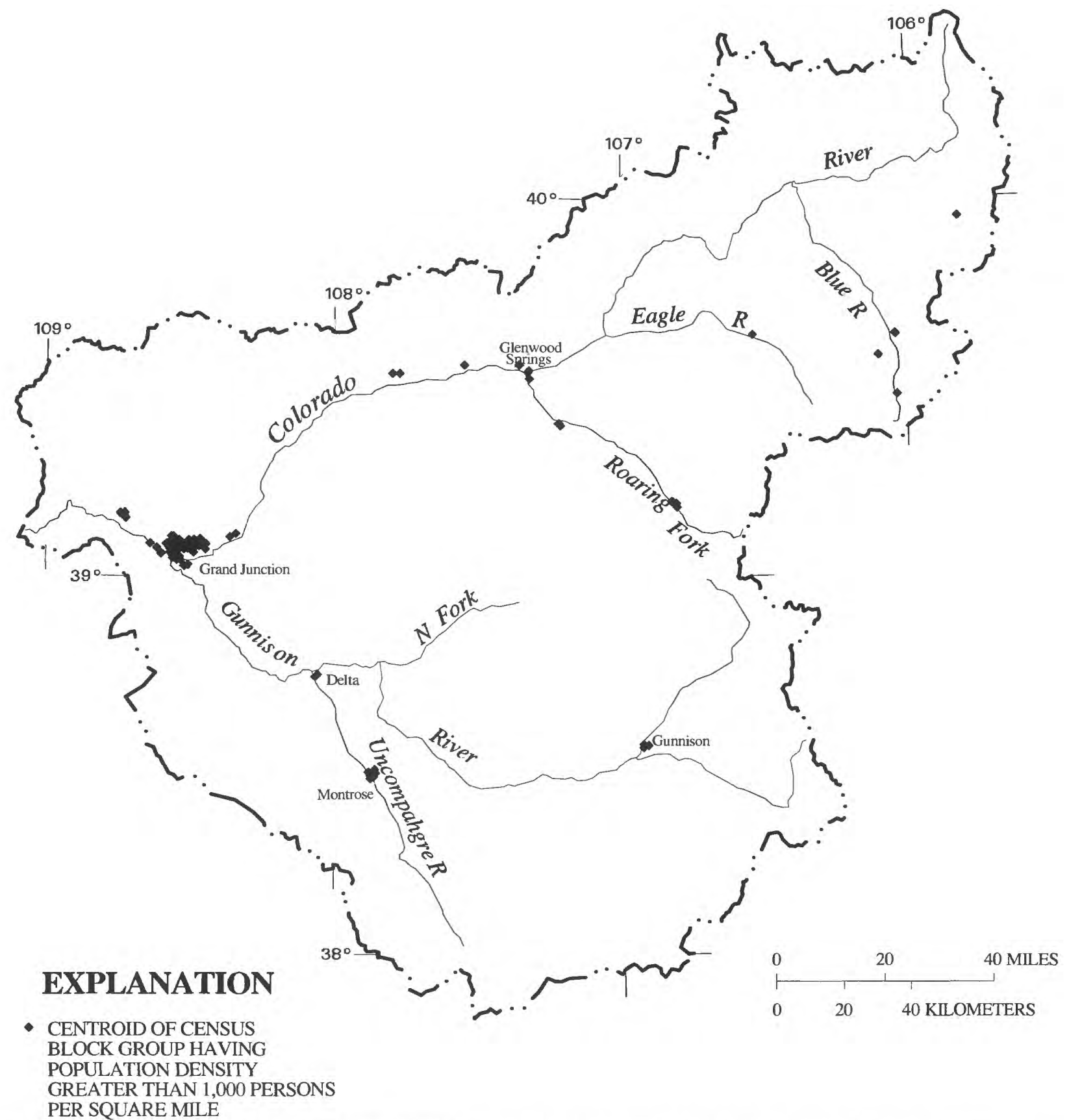

Figure 7. Population density in the Upper Colorado River Basin study unit (data from Bureau of Census, 1990). 


\section{Land Use}

Land designated for use as rangeland or forest in the study unit comprises the largest land use, accounting for about 85 percent of the study unit (fig. 8). Livestock (sheep and cattle) use large areas of rangeland for foraging. Forest land that includes most of the mountain and plateau areas is used for some commercial lumber production from lodgepole pine, Englemann spruce, and Douglas fir. Forest land also provides wildlife habitat and recreational opportunities.

Large parts of the study unit are set aside for recreational use, including all or parts of 4 National Park Service areas, 11 Forest Service wilderness areas, 11 State parks, numerous State Wildlife Management areas, and $17 \mathrm{ski}$ areas. Tourism and recreational activities are a major industry in the study unit.

Mining is another important land use in the study unit. Past and present mining activities have included the extraction of metals (copper, gold, lead, molybdenum, nickel, silver, vanadium, and zinc) and energy fuels (coal, gas, oil, oil shale, and uranium).

Urban land is one of the smaller land uses in the mostly rural Upper Colorado River Basin. A number of urban areas are associated with development activities resulting from the expansion of the ski industry and, in the 1980's, from energy-development activities. Historically, urban land use was associated with agricultural activities.

Agriculture is the traditional land use in the study unit in counties such as Delta, Garfield, Gunnison, Mesa, and Montrose. Agricultural activities include production of crops such as alfalfa, fruits, grains, hay, and vegetables. Little crop production is possible without irrigation because of the semiarid climate. Irrigated lands are predominantly in river valleys or low-altitude regions where the water is supplied by an extensive system of canals and ditches.

\section{Water Management}

Water management in the study unit is greatly affected by the 1922 Colorado River Compact and the 1948 Upper Colorado River Basin Compact. The 1922 Colorado River Compact divided the Colorado River Basin into upper and lower basins at Lee Ferry, Ariz., and apportioned the beneficial consumptive use. The 1948 Upper Colorado River Basin Compact apportioned the water of the upper basin to five States (Arizona, Colorado, New Mexico, Utah, and Wyoming) having drainage areas that contribute to the flow of the Colorado River. An annual total of 7.5 million acre-feet of water was apportioned to the upper basin, allocating 50,000 acre- $\mathrm{ft}$ annually to Arizona. The remaining water is allocated to the upper basin as follows: Colorado, 51.75 percent; New Mexico, 11.25 percent; Utah, 23 percent; and Wyoming, 14 percent (U.S. Department of the Interior, 1993).

In the Colorado River Basin, management of water quality has been greatly affected by three public laws: the Federal Water Pollution Control Act Amendments of 1972 (Public Law 92-500), required the establishment of a criterion for dissolved-solids concentrations; the Colorado River Basin Salinity Act (Public Law 93-320), established in 1974, authorized construction of 4 salinity-control projects and development of an additional 12 projects; and the 1984 amendment to Public Law 93-320 (PL98-589) gave authority to the Bureau of Reclamation and the U.S. Department of Agriculture to install salinity controls needed to meet the criteria for dissolved-solids concentrations.

In the study unit, there are 9 major interbasin water transfers exceeding 4,500 acre-ft/yr, 7 major water diversions, 9 major reservoirs, and 10 major municipal discharges for major cities in the basin. These structures are shown in figure 9 and listed in table 3. For water year 1993, the nine major interbasin water transfers conveyed about 585,000 acre- $\mathrm{ft}$ of water from the Upper Colorado River Basin to the South Platte, Rio Grande, and Arkansas River Basins. These interbasin water transfers provide supplementary irrigation and municipal water supplies to the receiving South Platte, Arkansas, and Rio Grande drainages. About 25 percent of the interbasin water transfers is for the municipal water supply for the Denver metropolitan area.

\section{Water Use}

Most of the water used in the study unit comes from surface-water sources; nevertheless, ground water is an important resource in remote and rural areas where the water predominantly is used for domestic purposes. Estimated offstream water use from surface water in the study unit during 1990 totaled about $3,500 \mathrm{Mgal} / \mathrm{d}$ as listed in table 4 . Ground-water sources accounted for less than 1 percent of the water used. The principal water use in the basin is for irrigation, which accounts for about 97 percent of the offstream water use (table 4 ). The remaining 3 percent is accounted for by the following in order of decreasing water use: livestock, domestic, power, industrial, commercial, and mining.

Consumptive use, which includes water that has evaporated, transpired, been incorporated into crops or products, or consumed by humans or livestock, 


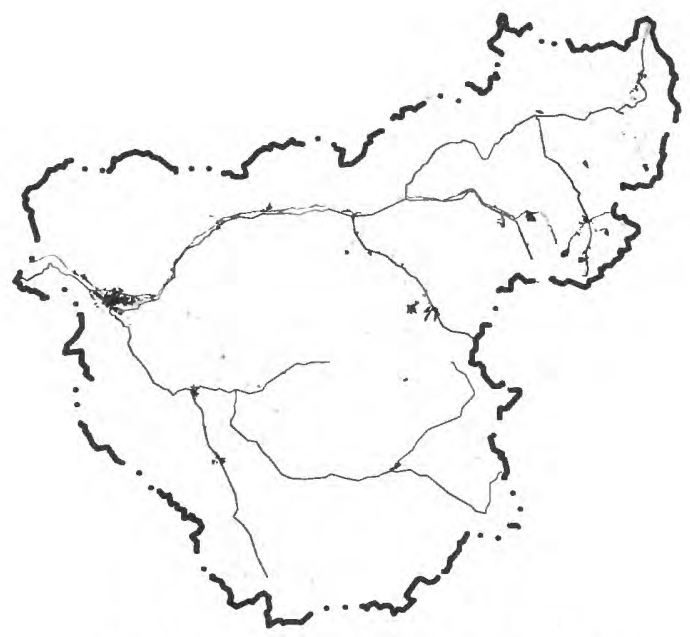

URBAN AND BUILT-UP LAND

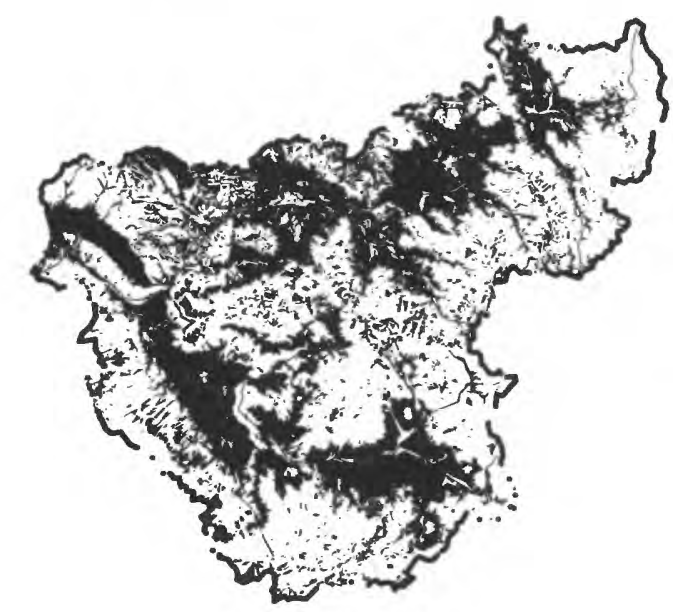

RANGELAND

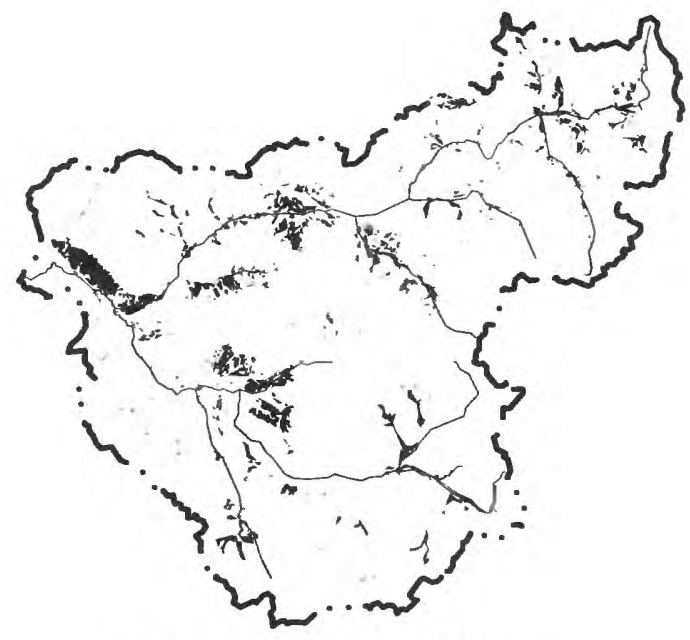

AGRICULTURAL LAND

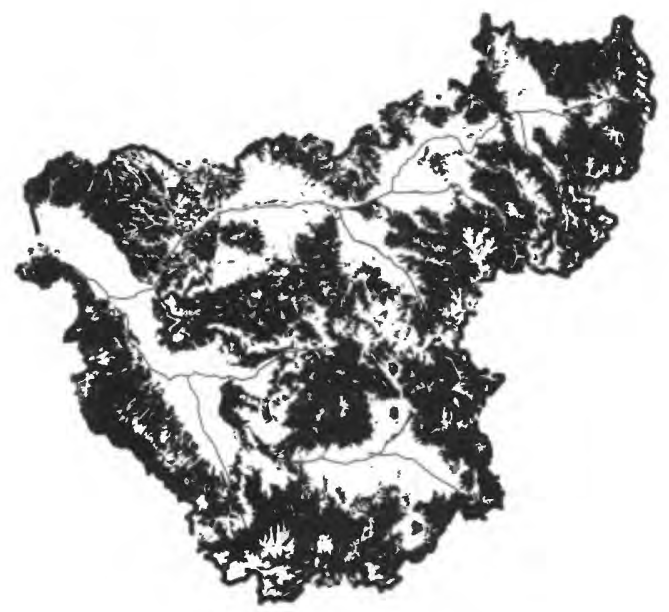

FOREST

O $20 \quad 40$ MILES

$0 \quad 20 \quad 40$ KILOMETERS

Figure 8. Major land use in the Upper Colorado River Basin study unit (modified from Marschner, 1967). 


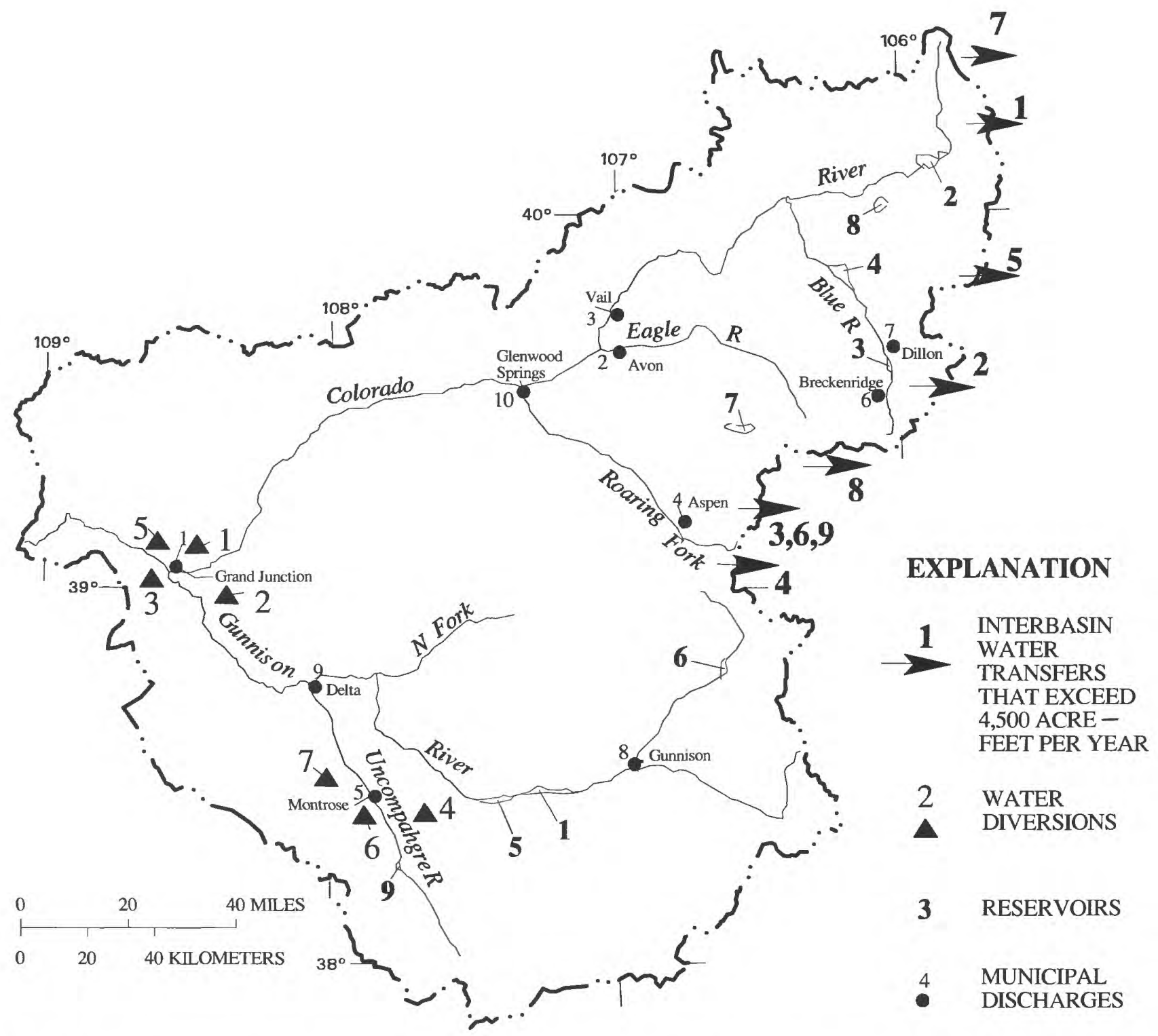

Figure 9. Major interbasin water transfers, water diversions, reservoirs, and municipal discharges in the Upper Colorado River Basin study unit. 
Table 3. Major interbasin water transfers, water diversions, reservoirs, and municipal discharges in the Upper Colorado River Basin study unit

[Map number coincides with numbers in figure 9. Data from Britton and Wentz, 1980; Northwest Colorado Council of Governments, 1989; Upper Colorado River Commission, 1993; Ugland and others, 1994]

\begin{tabular}{|c|c|c|}
\hline $\begin{array}{l}\text { Map number } \\
\text { (fig. 9) }\end{array}$ & Structure name & Water quantity \\
\hline \multicolumn{3}{|c|}{ Interbasin water transfers ${ }^{1}$ (acre-feet/yr) } \\
\hline 1 & Alva B. Adams Tunnel & 206,400 \\
\hline 2 & Harold D. Roberts Tunnel & 124,200 \\
\hline 3 & Charles H. Boustead Tunnel & 88,740 \\
\hline 4 & Twin Lakes Tunnel & 62,660 \\
\hline 5 & Moffat Water Tunnel & 34,470 \\
\hline 6 & Homestake Tunnel & 28,110 \\
\hline 7 & Grand River Ditch & 24,770 \\
\hline 8 & Hoosier Pass Tunnel & 11,040 \\
\hline 9 & Busk-Ivanhoe Tunnel & 4,980 \\
\hline \multicolumn{3}{|c|}{ Water diversions ${ }^{2}$ (acre-feet/yr) } \\
\hline 1 & Highline Canal & 852,000 \\
\hline 2 & Orchard Mesa Irrigation Ditches & 575,330 \\
\hline 3 & Redlands Canal & 517,700 \\
\hline 4 & Gunnison Tunnel (South Canal Montrose) & 331,000 \\
\hline 5 & Grand Valley Canal & 261,820 \\
\hline 6 & Montrose and Delta Canal (C Canal) & 189,890 \\
\hline 7 & Ironstone Canal & 113,890 \\
\hline \multicolumn{3}{|c|}{ Reservoirs $^{3}$ (acre-feet) } \\
\hline 1 & Blue Mesa Reservoir & 829,600 \\
\hline 2 & Lake Granby & 465,600 \\
\hline 3 & Dillon Reservoir & 254,000 \\
\hline 4 & Green Mountain Reservoir & 146,900 \\
\hline 5 & Morrow Point Reservoir & 121,200 \\
\hline 6 & Taylor Park Reservoir & 106,200 \\
\hline 7 & Ruedi Reservoir & 102,300 \\
\hline 8 & Williams Fork Reservoir & 96,820 \\
\hline 9 & Ridgway Reservoir & 84,590 \\
\hline \multicolumn{3}{|c|}{ Municipal discharges ${ }^{4}$ (acre-feet/yr) } \\
\hline 1 & Grand Junction & 7,448 \\
\hline 2 & Avon & 2,351 \\
\hline 3 & Vail Wastewater Plant & 2,145 \\
\hline 4 & Aspen Treatment Plan & 1,895 \\
\hline 5 & Montrose & 1,675 \\
\hline 6 & Breckenridge & 1,438 \\
\hline 7 & Silverthorne/Dillon & 1,395 \\
\hline 8 & Gunnison & 1,347 \\
\hline 9 & Delta & 1,217 \\
\hline 10 & Glenwood Springs & 873 \\
\hline
\end{tabular}

\footnotetext{
${ }^{1}$ Interbasin water transfers conveying greater than 4,500 acre-feet per year are listed. Data are for 1993.

${ }^{2}$ Water diversions greater than 100,000 acre-feet per year at inlet structure are listed. Data are for 1993.

${ }^{3}$ Reservoirs having normal capacity greater than 50,000 acre-feet are listed.

${ }^{4}$ Municipal discharges for major cities greater than 850 acre-feet per year are listed. Data are for 1993.
} 
Table 4. Estimated water use in the Upper Colorado River Basin study unit, 1990 (D.W. Litke, U.S. Geological Survey, written commun., 1995)

[Mgal/d, million gallons per day; ---, negligible]

\begin{tabular}{|c|c|c|c|c|c|}
\hline \multirow{2}{*}{ Water use } & \multicolumn{2}{|c|}{ Ground-water use } & \multicolumn{2}{|c|}{ Surface-water use } & \multirow{2}{*}{$\begin{array}{c}\text { Consumptive } \\
\text { use } \\
\text { (Mgal/d) }\end{array}$} \\
\hline & Mgal/d & Percent & Mgal/d & Percent & \\
\hline \multicolumn{6}{|c|}{ Offstream water uses } \\
\hline Commercial & 5.1 & 19 & 0.4 & --- & 1.5 \\
\hline Domestic (self, public) & 2.6 & 9 & 34.2 & 1 & 11.1 \\
\hline Industrial & 1.3 & 5 & 0.5 & ... & 1.2 \\
\hline Irrigation & 12.4 & 47 & 3,394 & 97 & 758 \\
\hline Power & 0 & 0 & 8.6 & --- & 0.08 \\
\hline Livestock & 1.0 & 4 & 61.4 & 2 & 3.7 \\
\hline Mining & 4.3 & 16 & 0.02 & --- & 1.1 \\
\hline Total offstream & 26.7 & & 3,500 & & 777 \\
\hline \multicolumn{6}{|c|}{ Instream water uses } \\
\hline Hydroelectric power & & & 3,132 & & 0 \\
\hline Reservoir evaporation & & & 110 & & 110 \\
\hline
\end{tabular}

predominantly is accounted for by irrigation in the basin. The remaining water-use categories account for less than 2 percent of the consumptive use.

Besides offstream water uses, there are instream water uses that are dependent on the amount of water flowing into a stream or the amount of water stored in a reservoir (table 4). The main instream use is for hydroelectric power generation, which accounts for about 3,132 Mgal/d of water. Reservoir evaporation accounts for about $110 \mathrm{Mgal} / \mathrm{d}$ of water.

\section{Hydrologic Characteristics}

The hydrologic characteristics of the basin can be represented by a generalized water budget (table 5). The budget listed in table 5 was estimated using 1993 data on water supply, distribution, and use in the study unit. This generalized budget can provide an understanding of the hydrologic system and the volume of water in the basin. The estimated average annual water input to the basin is about $20,980,000 \mathrm{acre}-\mathrm{ft} / \mathrm{yr}$. The source for water input in the area is precipitation (average precipitation is 22.1 in. distributed across the basin's $17,800 \mathrm{mi}^{2}$ ). Because the Upper Colorado River Basin is a headwaters system, no surface-water inflow occurs; the remaining water inputs by interbasin water transfers and ground-water inflow are negligible. Water outputs from the basin are more diverse, but the predominant output is from evapotranspiration from nonirrigated land, which accounts for about 70 percent of the total water output. The other major outputs for the basin are surface-water outflow at about 21 percent of the total basin output, consumptive water use (primarily evapotranspiration from irrigated lands) at about 4 percent, interbasin water transfers at about 3 percent, and reservoir evaporation at about 1 percent.

\section{Surface Water}

Streamflow has been measured at about 400 gaging stations in the study unit, and in 1993, 113 of these stations were active. The first gaging station in the area was established in 1894 on the Gunnison River near Grand Junction; however, a station on the Gunnison River below Gunnison Tunnel has operated continuously since October 1903 . This station has the longest record of operation in the study unit. Most active stations are located in the headwaters area of the mountains. Flow data are more scarce for the low-altitude areas.

Upper Colorado River Basin streams are classified in this report into three general types: high-altitude streams, low-altitude streams, and mixed-type streams. High-altitude streams are at altitudes above $7,500 \mathrm{ft}$ and receive $20 \mathrm{in}$. or more of precipitation annually, mostly in the form of snow. The basins for highaltitude streams have steep slopes and thin soils, which 
Table 5. Generalized water budget for the Upper Colorado River Basin study unit

\begin{tabular}{lrlr}
\hline \multicolumn{1}{c}{$\begin{array}{c}\text { Inputs } \\
\text { (acre-feet per year) }\end{array}$} & \multicolumn{2}{c}{$\begin{array}{c}\text { Outputs } \\
\text { (acre-feet per year) }\end{array}$} \\
\hline Precipitation & $20,980,000$ & Evapotranspiration from nonirrigated land (residual) & $14,910,000$ \\
Surface-water inflow & 0 & Surface-water outflow & $4,491,000$ \\
Interbasin water transfers (negligible) & 0 & Consumptive water use & 871,000 \\
Ground-water inflow (negligible) & 0 & Interbasin water transfers & $585,000^{1}$ \\
& & Reservoir evaporation & 123,000 \\
& & Ground-water outflow (negligible) & 0 \\
Total (rounded) & & Change in ground-water storage (negligible) & 0 \\
\hline
\end{tabular}

1 Data from U.S. Geological Survey National Water Information System and Upper Colorado River Commission, 1993.

promote efficient runoff; annual precipitation is sufficient to fully recharge the aquifers in most years, thereby maintaining base flow year round. Lowaltitude streams are at altitudes below $7,500 \mathrm{ft}$ and receive less than 20 in. of precipitation annually, mostly from thunderstorms. The basins for lowaltitude streams have flat slopes and thick deposits of soils and alluvium that attenuate runoff. Annual precipitation is insufficient to recharge aquifers to produce a continuous base flow. Mixed-type streams have headwaters in the mountains or high mesas but flow through the low-altitude regions.

Three stations have been selected to illustrate the differing flow characteristics of these stream types (table 6). The Colorado River below Baker Gulch (station 09010500, fig. 1) is on a high-altitude type stream having a drainage area of $53.4 \mathrm{mi}^{2}$ and a mean annual streamflow of $62.3 \mathrm{ft}^{3} / \mathrm{s}$. West Salt Creek near Mack (station 09153400, fig. 1) is on a low-altitude type stream and has a drainage area of $168 \mathrm{mi}^{2}$ and a mean annual streamflow of $0.88 \mathrm{ft}^{3} / \mathrm{s}$. This station only has 10 years of record and, therefore, flow characteristics at this station are not well defined. However, this record is among the longest for low-altitude streams in the basin that are not greatly affected by return flows or interbasin water transfers. The Colorado River near Cameo (station 09095500, fig. 1) is on a mixed-type stream and has a drainage area of $8,050 \mathrm{mi}^{2}$ and a mean annual streamflow of $3,870 \mathrm{ft}^{3} / \mathrm{s}$. This station is affected by interbasin water transfers, storage reservoirs, power development, and diversions for irrigation of about 160,000 acres.

Table 6. Hydrologic characteristics of selected surface-water stations in the Upper Colorado River Basin study unit $\left[\mathrm{mi}^{2}\right.$, square miles; $\mathrm{ft}^{3} / \mathrm{s}$, cubic feet per second; in., inches; Q-7-10, 7-day 10-year low flow; -, approximate]

\begin{tabular}{lccc}
\hline \multicolumn{1}{c}{ Hydrologic characteristic } & $\begin{array}{c}\text { Station } \\
\mathbf{0 9 0 1 0 5 0 0} \\
\text { Colorado River } \\
\text { below Baker } \\
\text { Gulch, } \\
\text { Colorado }\end{array}$ & $\begin{array}{c}\text { Station } \\
\mathbf{0 9 1 5 3 4 0 0} \\
\text { West Salt Creek } \\
\text { near Mack, } \\
\text { Colorado }\end{array}$ & $\begin{array}{c}\text { Station } \\
\mathbf{0 9 0 9 5 5 0 0} \\
\text { Colorado River } \\
\text { near Cameo, } \\
\text { Colorado }\end{array}$ \\
\hline Period of record (water year) & $1954-1993$ & $1974-1983$ & $1934-1993$ \\
Drainage area $\left(\mathrm{mi}^{2}\right.$ ) & 53.4 & 168 & 8,050 \\
Mean annual streamflow $\left(\mathrm{ft}^{3} / \mathrm{s}\right)$ & 62.3 & 0.88 & 3,870 \\
Coefficient of variation of annual mean streamflow & 0.33 & 1.03 & 0.30 \\
Mean annual runoff (in.) & 15.8 & 0.07 & 6.53 \\
10 -year flood $\left(\mathrm{ft}^{3} / \mathrm{s}\right)$ & 800 & $\sim 140$ & 28,000 \\
Q-7-10 $\left(\mathrm{ft}^{3} / \mathrm{s}\right)$ & 3.9 & 0 & 1,050 \\
\hline
\end{tabular}




\section{Annual and Monthly Flow Characteristics}

Annual flow varies substantially at all three stations (fig. 10). Variability is low at Colorado River below Baker Gulch (coefficient of variation of 0.33 ) because streamflow at the station is derived from snow, which accumulates over a season, and thereby is less variable. Variability is highest at West Salt Creek near Mack (coefficient of variation of 1.03) because streamflow primarily is derived from highly variable thunderstorms. Variability also is low at the Colorado River near Cameo (coefficient of variation of 0.30 ) because most streamflow is derived from snow, and annual flows have been affected by reservoir regulation and interbasin water transfers.

Monthly flow also varies substantially at the three stations (fig. 11). The Colorado River below Baker Gulch has snowmelt runoff from April through July, which is superimposed on a perennial base flow. The peak runoff period is May through June. West Salt Creek is an ephemeral stream, and streamflow results primarily from rainfall runoff. About 45 percent of the mean annual streamflow at West Salt Creek occurs during August, September, and October, whereas at stations where snowmelt predominates, the percentage of the mean annual streamflow during those 3 months is about 12 to 18 percent. The Colorado River near Cameo has increased runoff during the months of April through July because of snowmelt, but base flow is maintained at a larger, more constant level because of reservoir releases and irrigation-return flows.

\section{Floods and Droughts}

Streamflow, including flood flows, generally is more variable on low-altitude streams than on highaltitude and mixed-type streams in the study unit. High flows on high-altitude streams in the mountains tend to be less variable and of longer duration. They primarily result from snowmelt during late spring and early summer. Although the magnitude of these floods can be quite large, exceptionally large snowmelt floods that could cause severe flooding are very uncommon.

Because of the annual nature of snowmelt floods, most stream channels are capable of carrying these snowmelt floods without extensive bank overflow or substantial flooding (Chaney and others, 1987). Reservoir storage, interbasin water transfers, and local diversions for irrigation also diminish the magnitude of the annual snowmelt floods.

Frequency curves of annual maximum mean daily streamflow (fig. 12 ) indicate the probability that a given maximum mean daily streamflow will be equaled or exceeded in any given year. For example, there is a 10 percent probability that mean daily streamflow of $30,000 \mathrm{ft}^{3} / \mathrm{s}$ would be equaled or exceeded in any given year at the Colorado River near Cameo. Differences in the vertical position of these curves indicate differences in streamflow for an exceedance probability and primarily are the result of differences in drainage-area size (table 6). The steepness of the curve for West Salt Creek relative to the curve for Colorado River below Baker Gulch indicates that maximum mean daily streamflows are more variable on low-altitude streams than on high-altitude and mixed-type streams. The annual maximum mean daily streamflow curve for West Salt Creek is approximate because it is based on only 10 years of record. This short period of record affects the accuracy with which floods having a large probability of exceedance can be predicted. The slope of the curve for this station could change considerably with additional years of streamflow record.

Frequency curves of annual minimum mean 7-day streamflow (fig. 12) indicate the probability of nonexceedance between flows smaller than a specified magnitude. Low-altitude streams have extended periods of no flow and cannot be meaningfully analyzed for probability of nonexceedance. Therefore, West Salt Creek, which had at least 288 consecutive days of no flow recorded, is not shown. Low flows in highaltitude and mixed-type streams are sustained primarily by ground-water discharge, but gradual melting of perennial snowfields also provides some base flow. The shape of the annual minimum mean 7-day streamflow curves for the Colorado River below Baker Gulch and Colorado River near Cameo are similar. The greater magnitudes of low flow at Cameo for a specific probability of nonexceedance are a result of a larger drainage area, tributary inflows, and water-development factors such as reservoir releases, interbasin water transfers, and irrigation-return flows. At Cameo, 7 consecutive days of flows less than $1,050 \mathrm{ft}^{3} / \mathrm{s}$ can be expected 10 percent of the time. Knowledge about expected frequency of certain low flows is important because of the detrimental effects on stream biota resulting from dissolved-oxygen depletion and increased concentrations of dissolved constituents.

\section{Human Effects On Streamflow}

The natural hydrology of the Upper Colorado River Basin has been considerably altered by water development, which includes numerous reservoirs and diversions. The quantity of water removed from the basin by large interbasin water transfers to the South Platte, Rio Grande, and Arkansas River Basins was about 585,000 acre-ft in water year 1993. 

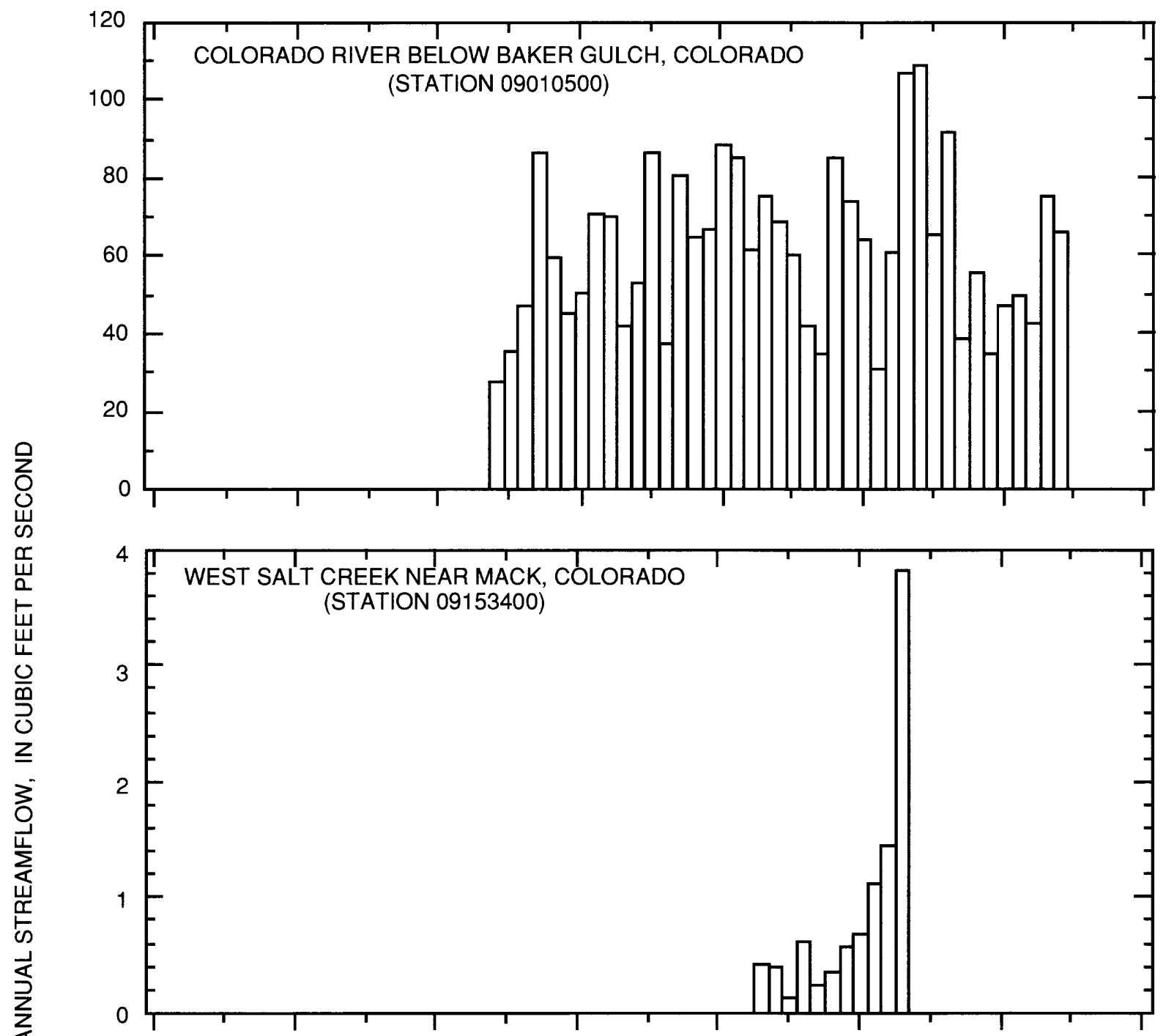

妄

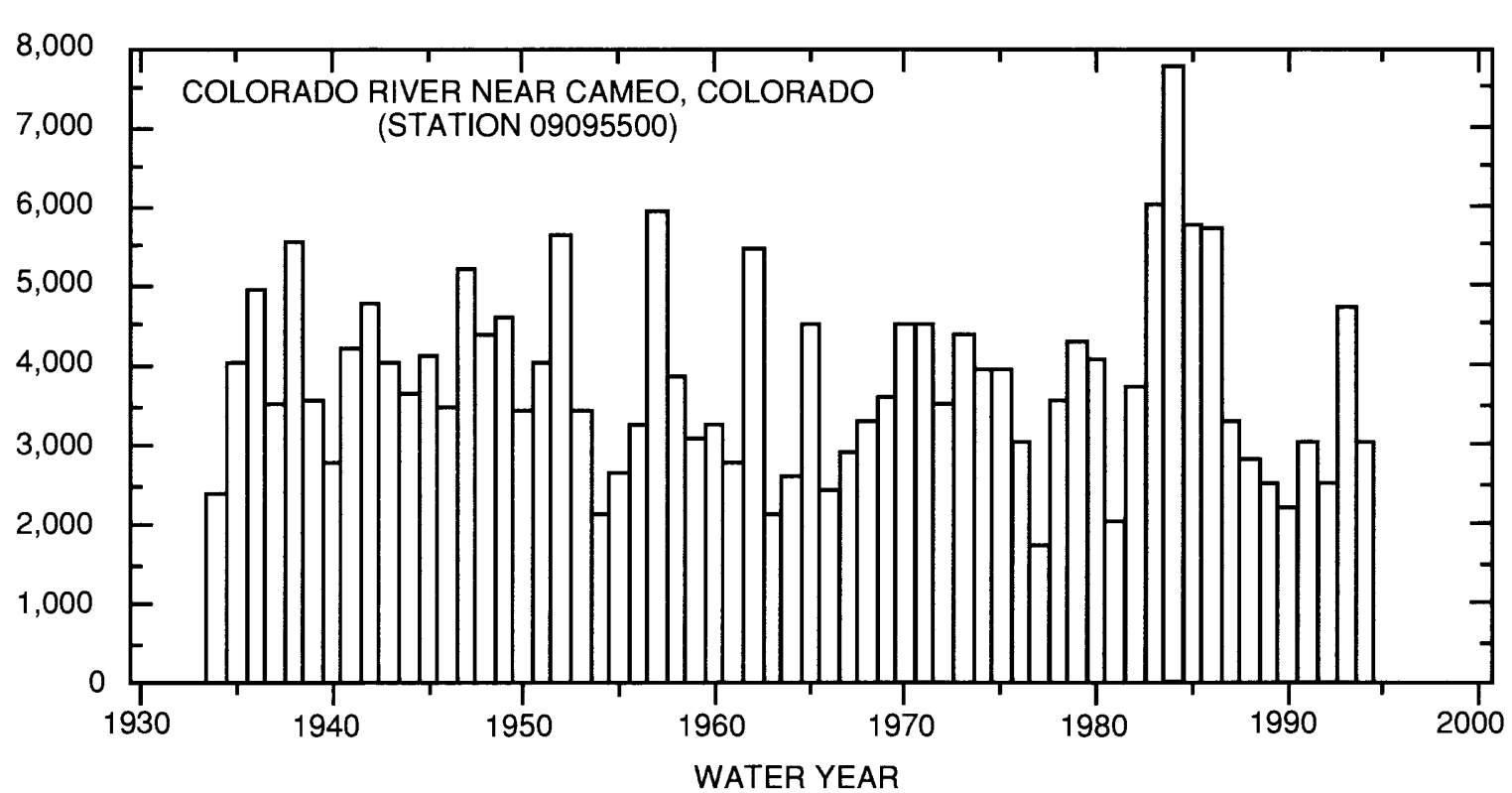

Figure 10. Mean annual streamflow at selected surface-water stations in the Upper Colorado River Basin study unit. 


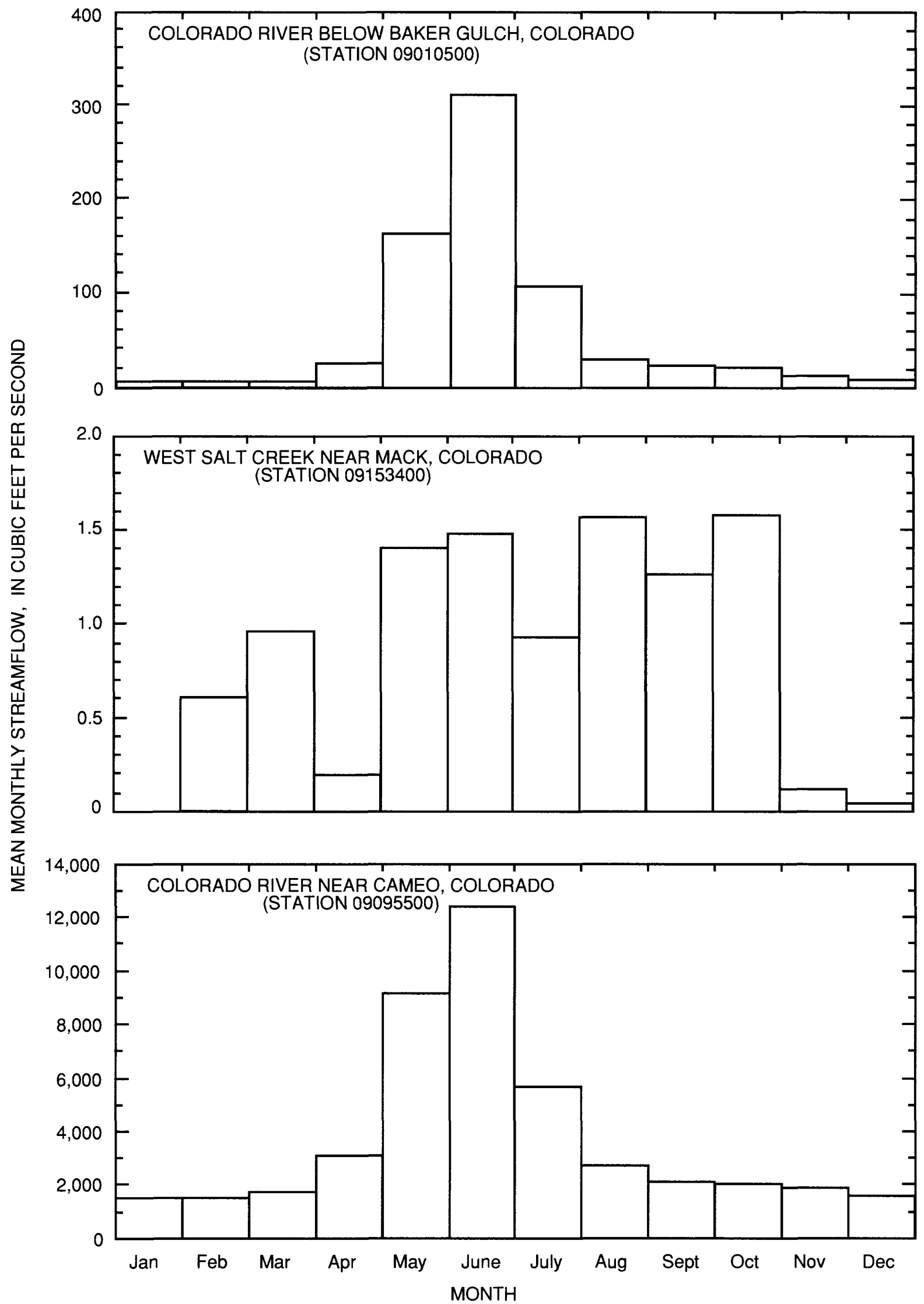

Figure 11. Mean monthly streamflow at selected surface-water stations in the Upper Colorado River Basin study unit. 

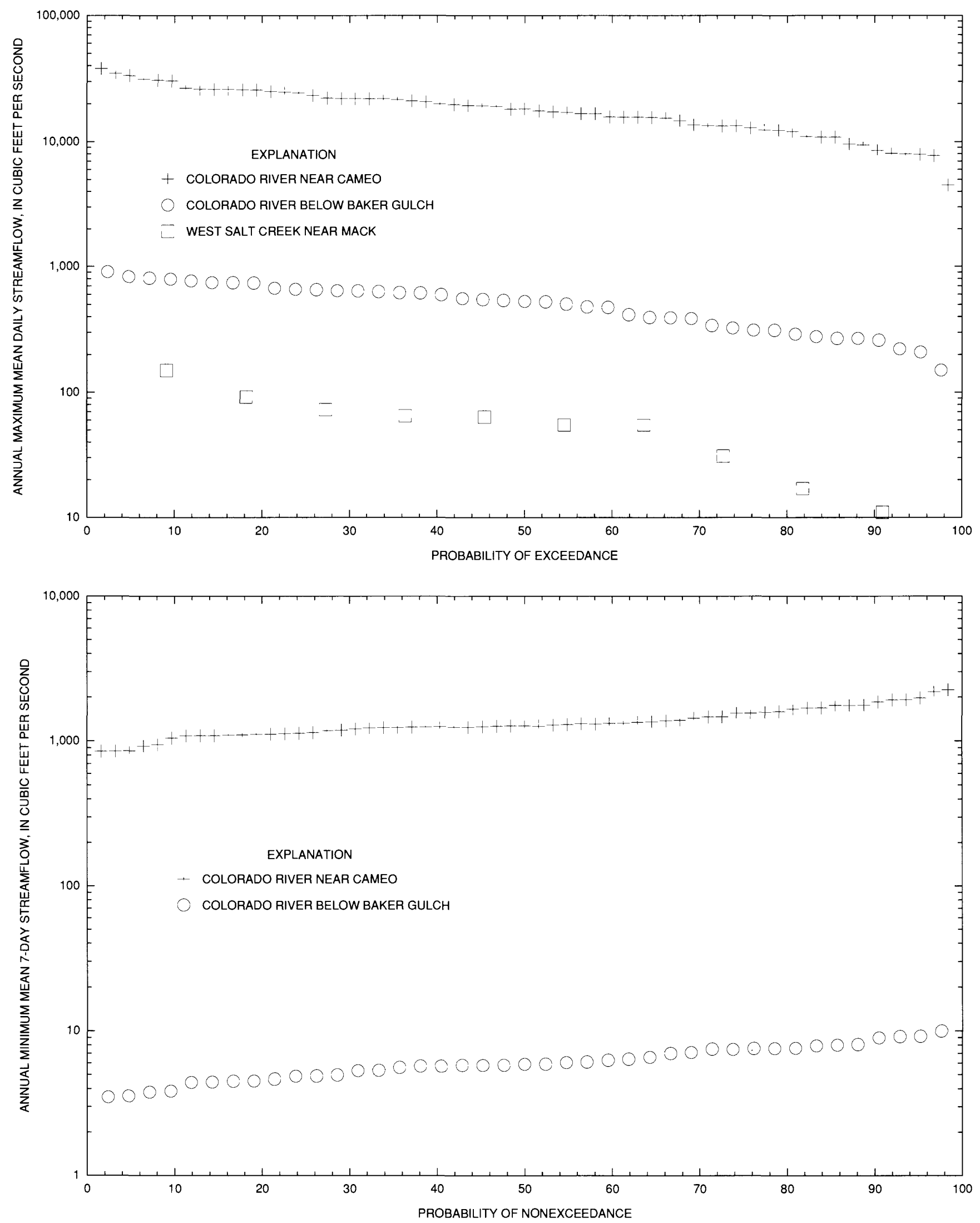

Figure 12. Streamflow probability of exceedance and nonexceedance at selected surface-water stations in the Upper Colorado River Basin study unit. 
An examination of flow conditions during water year 1993 gives a general representation of water routing along the Colorado River, although flows during water year 1993 were above average. Major interbasin water transfers and reservoirs are shown in figure 9 and listed in table 3. The Colorado River below Baker Gulch represents flow in the headwaters, although the Grand River ditch upstream from Baker Gulch diverted an annual flow of $71 \mathrm{ft}^{3} / \mathrm{s}$ in water year 1993. The Colorado River then flows into Shadow Mountain Reservoir/Lake Granby, from which water can be diverted through the Alva B. Adams Tunnel. This complex diversion and storage system was completed in 1950. Diversions from Grand Lake via the Alva B. Adams Tunnel to the South Platte River Basin are large during all months except June.

The first major tributary to the Colorado River is the Blue River. The Harold D. Roberts Tunnel, operating in conjunction with Dillon Reservoir, has diverted water from the Blue River Basin since 1963. Annual flows of $308 \mathrm{ft}^{3} / \mathrm{s}$ (1993) for the Blue River are affected by Dillon and Green Mountain Reservoirs. The Eagle River is the next major tributary adding $542 \mathrm{ft}^{3} / \mathrm{s}$ in water year 1993. Homestake Tunnel and Reservoir have diverted water from the Eagle River Basin since 1967. In water year 1993, the Colorado River had an annual flow of $2,330 \mathrm{ft}^{3} / \mathrm{s}$ downstream from the Eagle River and 3,970 $\mathrm{ft}^{3} / \mathrm{s}$ downstream from the Roaring Fork, which had an annual flow of $1,540 \mathrm{ft}^{3} / \mathrm{s}$ in water year 1993. The Twin Lakes Tunnel (completed in 1935) and the Charles H. Boustead Tunnel (completed in 1972) divert water from the Roaring Fork Basin.

Ruedi Reservoir (completed in 1968) regulates the flow downstream from the diversions to the Charles $\mathrm{H}$. Boustead Tunnel. Several small creeks flow into the Colorado River before it reaches Cameo where it had an annual flow of 4,667 ft $3 / \mathrm{s}$ in water year 1993 .

The largest tributary to the Colorado River in Colorado, the Gunnison River, flows into the Colorado River at Grand Junction. Three small interbasin water transfers export water from the Gunnison River headwaters to the Arkansas and Rio Grande Basins. Three large dams were built for power generation and water storage on the main channel of the Gunnison River as part of the Colorado River Storage Project. Together the reservoirs constitute the Wayne N. Aspinall Unit, formerly known as the Curecanti Unit. The largest and farthest upstream reservoir is Blue Mesa Reservoir; the others are Morrow Point Reservoir and Crystal Reservoir. Large volumes of water are diverted within the basin through the Gunnison Tunnel, which transports water from the Gunnison River to the Uncompahgre Valley for irrigation (table 3).
Streamflow in the Uncompahgre River at Delta is affected by inputs from the Gunnison Tunnel during April through October and by substantial evapotranspiration from about 90,000 acres of irrigated croplands. The annual flow for the Uncompahgre River in water year 1993 was $387 \mathrm{ft}^{3} / \mathrm{s}$. Ridgway Reservoir (completed in 1986) is located upstream from the Uncompahgre River at Delta station and affects the flow at this station. At the mouth of the Gunnison River near Grand Junction, the annual flow was $3,725 \mathrm{ft}^{3} / \mathrm{s}$ in water year 1993 . The natural flow of the Gunnison River is affected by diversions for irrigation of about 233,000 acres upstream from this station, storage reservoirs, and return flow from irrigated lands. The outflow of the basin, Colorado River near Colorado-Utah State line, had an annual flow in water year 1993 of $8,491 \mathrm{ft}^{3} / \mathrm{s}$, of which the Gunnison River contributed 44 percent.

\section{Ground Water}

In the study unit, ground-water resources have not been extensively developed. The most productive wells come from alluvial aquifers that are formed from gravel, landslide, terrace, and glacial deposits in the basin. Other ground-water resources include consolidated aquifer systems and fractured systems such as those in metamorphic and granitic rocks. These aquifer systems generally yield less water than the unconsolidated aquifers.

Some of the important aquifers in western Colorado in descending order of age are alluvial, Green River, Mesaverde, Mancos Shale unit, Dakota, Morrison, Entrada, Leadville, and Precambrian crystalline unit (table 7) (U.S. Geological Survey, 1985). In some instances, alluvial aquifers might be hydraulically connected to bedrock aquifers.

\section{Unconsolidated Aquifers}

Valley-fill alluvial aquifers along the Colorado River and other perennial streams provide some water for irrigation, public supply, and industrial use (U.S. Geological Survey, 1985). Alluvial aquifers in eroded intermontane valleys are thickest and most commonly saturated (Ackerman and Brooks, 1986). Thin aquifers are in alluvium and in eolian deposits on mesa tops. Aquifers on steep slopes of alluvium, talus, and colluvium are only seasonally saturated. The thickness of alluvial aquifers is less than the thickness of all bedrock aquifers in the basin. However, transmissivity is much larger in the alluvial aquifers as compared to the bedrock aquifers. 
Table 7. General hydrologic description of selected aquifers in the Upper Colorado River Basin study unit

[ft, feet; gal/min, gallons per minute; $\mathrm{mg} / \mathrm{L}$, milligrams per liter; $\mathrm{ft}^{2} / \mathrm{d}$, feet squared per day: --, no data. Data from Wilson, 1965; modified from U.S. Geological Survey, 1985; and from Warner and others, 1985]

\begin{tabular}{|c|c|c|c|c|c|}
\hline Aqulfer name and descriptlon & $\begin{array}{l}\text { Aqulfer } \\
\text { thlckness } \\
\text { (ft) }\end{array}$ & $\begin{array}{c}\text { Potential } \\
\text { yleld } \\
\text { (gal/m/n) }\end{array}$ & $\begin{array}{l}\text { Dlssolved- } \\
\text { sollds } \\
\text { (mg/L) }\end{array}$ & $\begin{array}{l}\text { Trans- } \\
\text { missIvlty } \\
\left(\mathrm{ft}^{2} / \mathrm{d}\right)\end{array}$ & Remarks \\
\hline
\end{tabular}
unconsolidated and only moderately sorted. Generally unconfined.

\section{Green River aquifer:}

Upper aquifer: coarse- to fine-grained silty sandstone and siltstone of the Uinta Formation and fractured dolomite marlstone. Generally confined.

Lower aquifer: Fractured dolomitic marlstone.

Generally confined.

Mesaverde aquifer: Marine sandstone with interbedded siltstone and shale; coal bearing in middle part of group. Confined. except near outcrop areas.

Mancos Shale unit: Silty and sandy marine shale; contains some interbedded sandstones and limestones. Unconfined.

Dakota aquifer: Sandstone with interbedded siltstone and carbonaceous shale; contains many

conglomerate lenses near base.

Confined.

Morrison aquifer: Fine- to mediumgrained, thin-bedded sandstone, and varicolored red and green shale.

Entrada aquifer: Medium- to very fine- grained sandstone with some silt and clay. Confined.

Leadville aquifer: Gray dolomitic limestone with some sandstone and chert. Confined.

Precambrian crystalline unit: Quartzbiotite gneiss and schist with some hornblende gneiss and quartzite; intruded by granite and quartz monzonite batholiths and other intrusives. Unconfined.

\section{Bedrock aquifers}

$500-1.000 \quad 10-500 \quad 400-2,000 \quad 10-600$

$600-2,000$

$$
2-50
$$

$500-40,000$

$10-600$

$1.000-1.500$

$$
1-10
$$

20-50

$1-10$

$200-4,800$

$200-1,000$

$$
1-25
$$

$300-3,500$

$$
500-700
$$

$$
1-25
$$

$$
0.5-5
$$$$
20-1,600
$$$$
<10
$$

Water exclusively in fractures. Potential of aquifer not developed. The lower aquifer commonly contains dissolved gas.

Water ranges from sodium bicarbonate type to calcium sulfate type, depending on presence or absence of shales.

Dissolved iron may exceed National drinking-water regulations.

Water contained in fractures or weathered zones. Water is predominantly sodium bicarbonate to sodium sulfate type.

Many wells flow at the surface. Water ranges from sodium bicarbonate to calcium bicarbonate type.

Water is calcium bicarbonate type.

Water generally sodium bicarbonate type. Some water contains dissolved hydrogen sulfide gas.

Potential of aquifer not developed. Water is a sodium bicarbonate type.

Water available only in fractures. 


\section{Bedrock Aquifers}

Bedrock aquifers in the study unit can be broadly grouped into Tertiary (Green River aquifer), Mesozoic (Mesaverde, Mancos Shale unit, Dakota, Morrison, and Entrada aquifers), Paleozoic (Leadville aquifer), and Precambrian crystalline unit. Tertiary rocks include fluvial sediments, marine sediments, and clastic deposits of sandstone and shale along with coal beds. Mesozoic rocks consist of siltstone, sandstone, shale, and limestone. Paleozoic rocks consist of carbonate (limestone and dolomite) and clastic sedimentary rocks. Precambrian rocks are composed of metamorphic and granitic rocks.

Wells completed in consolidated deposits commonly are less than $500 \mathrm{ft}$ in depth, but some can reach as much as 2,000 ft. The water yield from these wells varies from 0.5 to possibly greater than $500 \mathrm{gal} / \mathrm{min}$ (table 7). The ability for bedrock to transmit water depends on the rock lithology and structure. The effective porosity is largely affected by the wide range in lithologies, where tightly cemented sandstones can have a porosity of less than 10 percent, and in more poorly sorted sandstones consisting of medium- to coarse-grained sands, porosity can be greater than 30 percent. As indicated in table 7 , the transmissivity of three bedrock aquifers is about 10 to $20 \mathrm{ft}^{2} / \mathrm{d}$, but can be as high as $600 \mathrm{ft}^{2} / \mathrm{d}$ in the Green River aquifer.

\section{Water Movement}

Ground-water movement in the Upper Colorado River Basin is similar to surface-water flow directions. In the eastern part of the study unit, the flow system primarily involves recharge in the mountainous areas and discharge in the lower valleys. Recharge in the western part of the basin is due to precipitation in the form of snow or rain and discharge occurs in the valleys (Chaney and others, 1987). Most ground water is discharged into streams through seeps along the side or bottom of the stream channel or to the land surface by springs.

The rate and quantity of ground-water movement depend on the hydraulic conductivity of the geologic formation and the hydraulic gradient. In the basin, alluvial deposits, other unconsolidated sedimentary deposits, and limestones have high hydraulic conductivity and transmit water fairly readily. The transmissivity value listed in table 7 indicates the ability of alluvial deposits to transmit water. In consolidated sedimentary, igneous, and metamorphic rocks, water moves primarily through fractures.

\section{Stream-Aquifer Relations}

Some aquifers in the basin are hydraulically connected to the surface water as ground water discharges into main river channels through springs where the aquifer is near the surface or by upward movement of the ground water if the aquifer is located at depth. During low flows, ground water helps sustain streamflow on practically every perennial stream throughout the year (Chaney and others, 1987). Perennial storage in alluvial aquifers, perennial snowfields, and reservoirs in the basin provide sustained base flows. Bedrock aquifers also can contribute to streamflow during low-flow periods on perennial streams. However, the amount of water contributed to perennial streams by bedrock aquifers varies seasonally. Water levels in the bedrock aquifers can change because of physical factors, such as climatic conditions, irrigation, and pumping wells, and because of the relative transmissive and storage properties of these aquifers (McLean and Johnson, 1988). Ephemeral streams occur due to a drop in the water table below streambeds, a result of insufficient storage water within the aquifers.

\section{Aquatic Biological Characteristics}

The Upper Colorado River Basin provides diverse habitats for biological communities, reflecting the variations in climate, vegetation, and geology in the basin (Ward and others, 1986). In table 8, algae, fish, and macroinvertebrates are listed that characterize the Southern Rocky Mountains and the Colorado Plateau physiographic provinces. This listing includes the more common taxa in each physiographic province but does not include all algae, fish, and macroinvertebrates in the study unit. Biological communities vary with altitude and physical habitat.

Different algal species are affected by varying riparian vegetation as well as by the availability of nutrients. The dominant algae in the high-altitude streams are blue-green algae, diatoms, dinoflagellates, golden-brown algae, and green algae. In more saline environments, euglenoid algae may be present. In the lower altitudes, golden-brown and green algae are predominant.

The high-altitude streams in the Southern Rocky Mountains are dominated by brook, brown, cutthroat, and rainbow trout and other cold-water species, such as creek chubs, flathead minnows, sculpins, speckled dace, and white suckers. Lower altitudes, as characterized by the Colorado Plateau, can contain cold-water and warm-water species because of overlap in transition zones. Trout are present at the higher altitudes of 
Table 8. Major aquatic biological taxa in the Southern Rocky Mountains and Colorado Plateau physiographic provinces of the Upper Colorado River Basin study unit
Taxonomic group
Southern Rocky Mountains
Colorado Plateau

\begin{tabular}{|c|c|c|}
\hline \multirow[t]{6}{*}{ Algae $^{1}$} & Chlorophyta (green algae) & Chlorophyta \\
\hline & Chrysophyta & Chrysophyta \\
\hline & Bacillariophyceae (diatoms) & Bacillariophyceae \\
\hline & Chrysophyceae(golden-brown algae) & Chrysophyceae \\
\hline & Cyanophyta (blue-green algae) & Cyanophyta \\
\hline & Pyrrhophyta (dinoflagellates) & Euglenophyta (euglenoid algae) \\
\hline \multirow[t]{9}{*}{ Fish $^{2}$} & Salmonidae (salmon and trout) & Salmonidae \\
\hline & Cyprinidae (minnows and carp) & Cyprinidae \\
\hline & Catostomidae (suckers) & Catostomidae \\
\hline & Percidae (perches) & Percidae \\
\hline & Cottidae (sculpins) & Cottidae \\
\hline & Esocidae (Northern Pike) & Ictaluridae (catfish) \\
\hline & & Cyprinodontidae (topminnows and killifis \\
\hline & & Poeciliidae (mosquitofish) \\
\hline & & Centrarchidae (bass and sunfish) \\
\hline \multirow[t]{12}{*}{ Macroinvertebrates $^{3}$} & Ephemeroptera (mayflies) & Ephemeroptera \\
\hline & Trichoptera (caddisflies) & Trichoptera \\
\hline & Diptera (true flies) & Diptera \\
\hline & Coleoptera (beetles) & Coleoptera \\
\hline & Odonata (dragonflies and damselflies) & Odonata \\
\hline & Plecoptera (stoneflies) & Megaloptera (alderflies and dobsonflies) \\
\hline & Amphipoda (scuds) & Amphipoda \\
\hline & Oligochaeta (worms) & Oligochaeta \\
\hline & Tricladida (flatworms) & Decapoda (crayfish) \\
\hline & Nematoda (roundworms) & Gastropoda (snails) \\
\hline & Gastropoda (snails) & Hirudinea (leeches) \\
\hline & Hirudinea (leeches) & \\
\hline
\end{tabular}

\footnotetext{
${ }^{1}$ Colorado Department of Heal th (1976); Apley (1982); Natural Energy Resources Company (1987)

${ }^{2}$ Everhart and Seaman (1971); Woodling (1985)

${ }^{3}$ Federal Water Pollution Control Administration (1968); Ward and others (1986); Ward and Kondratieff (1992)
}

the basin; and basses, carp, catfish, minnows, perches, and suckers dominate the lower altitudes. The Upper Colorado River Basin contains four fishes presently listed as endangered by the U.S. Fish and Wildlife Service (Behnke and Benson, 1980). The four species are the Bonytail chub (Gila elegans), the Colorado squawfish (Ptychocheilus lucius), the Humpback chub (Gila cypha), and the Razorback sucker (Xyrauchen texanus). They are all found in the warmer waters of the Colorado Plateau.

Macroinvertebrate communities vary with altitude, amount of dissolved oxygen, substrate, water temperature, and vegetation. Beetles, caddisflies, may- flies, stoneflies, and true flies comprise the majority of the species present in the high-altitude streams. In the transition from high-altitude to low-altitude streams, caddisflies, mayflies, and true flies become less dominant; stoneflies are rare; and crayfish, dobsonflies, and scuds are present. Also, the physical environment, such as changes in water temperature and substrate of the streams at lower altitude, is favorable to providing habitat for additional species such as dragonflies, leeches, and snails.

Although the Southern Rocky Mountains and the Colorado Plateau contain similar biological communities, the controlling factors that determine these 
communities can be compared. The major controlling factors that determine composition of biological communities are changes in water temperature, water discharge and velocity, substrate and suspended material, chemical conditions, and aquatic and riparian vegetation (Ward and Kondratieff, 1992). The differences in biological communities between the Southern Rocky Mountains and the Colorado Plateau are the result of a combination of these factors.

\section{IMPLICATIONS OF ENVIRONMENTAL SETTING ON WATER QUALITY}

Water quality in the Upper Colorado River Basin is affected by the physical, chemical, and biological characteristics that make up the environmental setting. The availability of mineral and organic materials to the hydrologic system affects the water quality in the basin. Materials dissolved in or removed from the water can result from natural or human factors. In this section, the major natural and human factors that affect regional water quality are described in the context of the environmental setting. A general description of the occurrence and distribution of selected constituents is based on summaries by Chaney and others (1987); U.S. Geological Survey (1988); Liebermann and others (1989); and Colorado Department of Health (1992).

\section{Natural Factors}

Climate is an important natural factor affecting water quality as a result of changes in altitude, precipitation, runoff, and evaporation. The weathering processes of geologic formations are affected by air temperature, which is a function of altitude and distribution of precipitation in the basin. In the higher altitudes, precipitation can exceed $40 \mathrm{in} / \mathrm{yr}$; however, the Precambrian rocks and Tertiary volcanic rocks exposed at these higher altitudes are fairly resistant to weathering, and the concentrations of dissolved solids in the water are limited in these upper stream reaches. When the streams come in contact with outcrops of sedimentary rocks in the middle and lower reaches, the dissolved-solids concentrations in the water increase. In the more arid climate at lower altitudes in the western part of the basin, precipitation commonly in the form of thunderstorms generally is less than $10 \mathrm{in} / \mathrm{yr}$, but the thunderstorms can mobilize runoff of large loads of sediments and solutes to the streams. In addition, evaporation in the semiarid to arid climate enhances the precipitation of dissolved solids.

Water quality also can be affected by the chemistry of precipitation. In the study unit, there are consid- erable chemical inputs from atmospheric deposition of nutrients and major ions. Two National Atmospheric Deposition Program sites for monitoring constituents in the atmosphere are located near the Glenwood Springs area, and a number of other sites surround the basin. The loading of nitrate in the mountainous areas near the basin can be an important part of the nutrient budget for high-altitude lakes. Also, concentrations of nitrate in precipitation are several orders of magnitude greater than concentrations measured in high-mountain streams (J.T. Turk, U.S. Geological Survey, oral commun., 1995). In the Colorado Plateau, the atmospheric contribution is secondary to the human effect from agricultural and municipal sources. Atmospheric inputs could be a source of metals and organic compounds, especially in the mountainous areas of the basin, but their significance has not been documented.

Geologic formations affect water quality because rocks are the source of many chemical constituents in the water. Soluble salts, minerals, and trace elements from different geologic formations result in increased dissolved-solids concentration and determine the chemical composition of the streams. In the Southern Rocky Mountains province, water-quality conditions are related to trace elements, which occur naturally in geologic formations and soils-most commonly cadmium, copper, lead, and zinc. In the Eagle River Valley where the Eagle Valley Evaporite is exposed, moderately soluble gypsum and other salts that are present in this formation affect the water quality. Within the Piceance Structural Basin, the Mancos Shale and Mesaverde Group are present, and weathering of these units adds dissolved-solids concentration to the surface and ground water. Also, in the western part of the study unit, weathering of authigenic pyrite in the Mancos Shale results in increased selenium concentration in the surface and ground water (Wright and Butler, 1993). Geologic formations along the Colorado River and Gunnison Valley have radioactive substances, such as uranium, radon, and radium, that occur naturally, and concentrations of these elements are present in the surface and ground water.

However, the single geologic factor having the most effect on quality of water in western Colorado is the many mineral springs present in the study unit. At Glenwood Springs, all springs issue from the Leadville Limestone or alluvium overlying the Leadville Limestone and Belden Formation (table 1) (Geldon, 1989). Amounts ranging from 475,000 to 534,000 tons of dissolved solids are added annually from the springs to the surface water (Warner and others, 1985; Liebermann and others, 1989).

Soils affect water quality as a source of suspended sediment and soluble materials. Soils in the 
mountains generally are thin and poorly developed and primarily are a product of physical weathering of rocks. Soils in the Colorado Plateau are thicker and are formed on deposits of recent geologic age. Suspended sediment in the basin predominantly is a result of channel erosion and soil erosion from overland flow. Generally, suspended-sediment concentrations increase from the eastern edge of the Colorado Plateau physiographic province to the outflow of the basin at the Colorado-Utah State line. Suspended-sediment concentrations are smallest during base-flow conditions and largest during spring runoff when streamflow discharges are large and sediment is available. Soils in the agricultural areas of the basin contain soluble salts that could greatly affect the concentrations of sodium and calcium in the surface and ground water.

\section{Human Factors}

Human factors can adversely affect water quality as a result of point and nonpoint sources of chemical constituents. Because the economy of the mountainous region depends on outdoor recreation and water-based activities, such as fishing, white-water boating, flatwater boating, camping, and hiking, this area is a priority to the State's water-quality program. For example, State water-quality standards for aquatic life have not been met for cadmium, copper, lead, and zinc in streams downstream from active and abandoned mines in the headwaters. In addition, many of the shallow, unconfined aquifers in Colorado have become contaminated with nitrates and salinity resulting from agricultural activities (Colorado Department of Health, I992). Human factors also can improve water quality; for example, reservoirs can trap sediments and metals, resulting in downstream reaches having better water quality than the upstream reaches.

Human factors can be described according to the water and land uses discussed earlier in this report. Interbasin water transfers, mining, urbanization, and agriculture are the principal activities that affect water quality in the basin. In the Upper Colorado River Basin, these activities occur approximately in a downstream order. Interbasin water transfers are in the headwaters, mining is located in the mountainous areas, urbanization is in the Southern Rocky Mountains and Colorado Plateau, and agriculture predominantly is in the valleys of the Colorado Plateau.

Because interbasin water transfers generally are made near the stream headwaters, the amount of streamflow diverted can be a substantial part of the streamflow near these sources; however, the effect decreases farther downstream as the volume of flow increases. Diversions from the basin account for about I2 percent of the mean annual streamflow at the Colorado River near the Colorado-Utah State line. The Alva B. Adams Tunnel, which diverts the largest amount of water in the entire study unit, may be the cause of increases in dissolved-solids concentrations in the Colorado River near Glenwood Springs (Liebermann and others, 1989). Although 9,000 tons of dissolved solids are removed annually from the Upper Colorado River Basin through the Alva B. Adams Tunnel, the principal effect of this diversion is the removal of relatively pure water from the Colorado River system.

Mining practices have affected water quality in several parts of the basin. The headwaters of several tributaries to the Colorado River such as the Blue, Eagle, Roaring Fork, and Gunnison Rivers drain one of the primary metal-mining regions in Colorado. A large number of active and abandoned metal mines exist in this region, which is referred to as the Colorado Mineral Belt. Metal-mining activities usually are in areas of high precipitation, resulting in a greater risk of perennial or ephemeral mine drainage as well as storminduced mine drainage from mine dumps and tailings. Streams have been affected by point-source mine discharge and nonpoint-source runoff from mined areas (Wentz, 1974). Concentrations of cadmium, copper, iron, lead, manganese, mercury, molybdenum, and zinc exceed State water-quality standards for localized reaches of these streams (Colorado Water Quality Control Division, 1989). Some reaches in the basin, such as Red Mountain Creek near Ouray, are affected by acid mine drainage. Although local reaches of these streams have been affected, little is known about the transport of these metals downstream into the larger tributaries and the Colorado River.

Coal mining in the area can affect water quality by increases in dissolved solids, particularly sulfate, and increases in trace-element concentrations. There are a number of active oil and gas fields and large deposits of oil shale, primarily in Garfield County. Although the effects from oil and gas drilling on the surface and ground water can be considerable locally, little is known as to the areal extent of the effects from this activity. Uranium mining was once active in the basin, and mining and milling wastes pose serious threats to ground water from radionuclide contamination. High radium concentrations occur in shallow aquifers in Montrose County in association with uranium mining and milling operations (Colorado Department of Health, 1992).

Urbanization has an important effect on the water quality of the study unit. Population is increasing at a rate of about 10 percent annually in some of the 
mountain communities in the headwaters of the study unit (Bureau of Census, 1992). In addition, the headwaters of the region are subject to increasingly intense year-round recreational activity. Point-source pollution from urbanization includes discharge from wastewater-treatment plants, solid-waste disposal, leaking underground storage tanks, industrial discharges, and storm runoff, which also is a nonpoint source. All these sources have a potential to affect the surface and ground water by adding nutrients, pesticides, various chemicals, hydrocarbons, trace elements, and salts depending on the specific point source. Because of the naturally low phosphorus concentrations that probably limit algal growth, reservoirs, such as Dillon, can be extremely sensitive to additional phosphorus loading, which leads to accelerated eutrophication (Colorado Department of Health, 1992). Advanced wastewater treatment for many municipal facilities and control of nonpoint sources of pollution from urban areas that discharge into Dillon Reservoir and the Fraser River, Eagle River, Roaring Fork, and several other tributary streams have been necessary to maintain water quality. Many streams in the study unit tend to have higher $\mathrm{pH}$ values than in other basins of the State; therefore, strict un-ionized ammonia standards $(0.02 \mathrm{mg} / \mathrm{L})$ have been required of wastewater facilities to protect cold-water aquatic life (Colorado Department of Health, 1992). In the mountain areas, communities and resorts generally are located in narrow valleys containing highly permeable gravelly sediments, which have some nitrate contamination in localized, shallow ground water. In areas where septic tanks are used for waste disposal instead of community waste-treatment systems, nitrate contamination is especially likely. Aquifers in fractured rocks of the mountainous areas also are vulnerable to nitrate contamination from individual septic systems. Nitrate contamination probably will continue to be the most widespread ground-water problem in Colorado (Colorado Department of Health, 1992).

There are a number of potential agricultural nonpoint-source-pollution issues in the lower region of the basin. Agriculture in the basin can produce increased levels of salinity, sediments, nutrients, pesticides, selenium, and other trace elements, which have an adverse effect on the surface water, ground water, and biological habitats.

Salinity is an important water-quality concern in the agricultural areas of the basin. High dissolvedsolids concentrations occur in irrigated areas near the lower Gunnison and lower Colorado Rivers and their tributaries (Colorado Water Quality Control Division, 1989). Irrigation-return flows, as seepage from canals and reservoirs and from field irrigation, are the largest human source for dissolved-solids concentrations in the study unit. The sedimentary geologic units, which include a large part of the central and lower parts of the basin, contain soluble minerals that contribute to the dissolved-solids concentrations. Surface water that is diverted for irrigation is applied to fields and a large amount is lost to evapotranspiration. This process concentrates the dissolved solids in the remaining water that eventually returns to the stream. Also, the reuse of water has a high potential to increase salinity in the Colorado River. Agricultural practices also can add to the salinity problem as a result of natural chemical processes. The chemical process involves transforming calcium sulfate (gypsum) to sodium sulfate by cation exchange in solution. Since sodium sulfate has a higher solubility in solution than calcium sulfate, the sodium concentration will be increased in the surface water. The cation-exchange process can result from irrigation practices or storm runoff.

Sediments are formed as a result of erosion and runoff processes. These processes are affected by soil type, land slope, climate, and tillage practices, which all affect the movement of contaminants to surface and ground waters. Sediment erosion by wind and water can be increased by cultivation practices and by livestock that trample stream banks, which occurs in many semiarid to arid climates like the Colorado Plateau. Soil permeability is a key factor affecting water quality in agricultural areas. In areas of well-drained soils, such as alluvial valleys in the basin, nitrate and pesticide concentrations can increase locally in alluvial aquifers beneath cropland that is fertilized, particularly where irrigated. Although phosphorus is at low levels throughout the basin, in areas of poorly drained soils, nitrogen and phosphorus from cropland fertilizers move to the surface water as surface runoff. Manure can contribute nitrogen to reservoirs and streams. Nitrate generally is at low levels in the basin, but is at higher levels in the Roan Creek, Uncompahgre River, and lower Colorado River reaches, because the reaches receive large quantities of drainage water from irrigation. Pesticide data are limited for surface and ground water. The areal distribution of data sites, the number of samples per site, and the temporal distribution of samples are inadequate for an assessment of pesticide distribution and occurrence.

Selenium concentrations in the Gunnison and Uncompahgre Rivers exceed U.S. Environmental Protection Agency criteria for protection of aquatic life, and the concentrations can be of concern for fish and waterfowl (U.S. Environmental Protection Agency, 1987). The Colorado River downstream from the Gunnison River and the lower reaches of the Gunnison River provide habitat for endangered fish 
and birds. The Uncompahgre Project area is a major source of selenium to the Gunnison River, and the effects of selenium on the endangered fish and birds in this area are not known (Butler and others, 1991). The presence of other trace elements in the water supply can result from irrigation. This is due to reuse of irrigation water and leaching of naturally occurring trace elements from the soils.

\section{SUMMARY}

The goals of the U.S. Geological Survey's NAWQA program are to describe current conditions for a large part of the Nation's surface- and groundwater resources, describe how water quality is changing over time, and identify the major natural and human factors that affect the water quality. The Upper Colorado River Basin study is 1 of 60 study units selected for water-quality assessment. Information about the environmental setting provides a framework of the basin characteristics and includes natural and human factors that affect the physical, chemical, and biological quality of the water in the basin. This information can be used to design data-collection studies in the study unit for the NAWQA program and can aid in determining the effects of natural conditions and human factors on water quality in the basin.

The study unit has a drainage area of about $17,800 \mathrm{mi}^{2}$, and the primary river within the basin, the Colorado River, originates in the mountains of central Colorado and flows about $230 \mathrm{mi}$ southwest into Utah. The major tributaries to the Colorado River in the study unit are the Blue, Eagle, Roaring Fork, and Gunnison Rivers. In 1990, population in the basin was about 234,000 . The largest population center in the basin is in the area around Grand Junction.

Climate in the basin varies from alpine conditions in the eastern part to semiarid in the western part. Mean annual precipitation ranges from more than $40 \mathrm{in}$. at the higher altitudes to less than $10 \mathrm{in}$. in the lower altitudes of the basin. The geology predominantly consists of crystalline rocks of Precambrian age, stratified sedimentary rocks, and alluvial deposits.

Land designated for use as rangeland or forest accounts for about 85 percent of the use in the basin. The other major land uses in the basin are agriculture, mining, and urban. Water used from surface water for irrigation accounts for about 97 percent of the total offstream water use. Ground water, which accounts for less than 1 percent of water used, typically is used for domestic purposes in the rural parts of the basin.

Study unit streams are classified in this report into three general types: high-altitude streams, lowaltitude streams, and mixed-type streams. Annual, seasonal, flood, and low flows in these three stream types vary considerably in the basin. The natural hydrology has been extensively altered by water development, which includes numerous reservoirs and diversions.

In the study unit, ground-water resources have not been extensively developed. The most productive wells come from alluvial aquifers in the basin. Other ground-water resources include consolidated aquifer systems in sedimentary rocks and fractured systems such as those in metamorphic and granitic rocks.

Algae, fish, and macroinvertebrates that are characteristic of the Southern Rocky Mountains and Colorado Plateau physiographic provinces vary with altitude and physical habitat. The dominant algae in the high-altitude streams are blue-green and green algae. In the lower altitudes, golden-brown and green algae are predominant. Cold water species, such as trout, are present at the higher altitudes, and warmwater species, such as carp, catfish, minnows, and suckers, dominate the lower altitudes. In the higher altitudes, caddisflies and mayflies are the dominant macroinvertebrates. The lower altitudes are favorable to species such as leeches and snails.

Natural and human factors affect the physical, chemical, and biological characteristics in the basin, which then affect the water quality. The natural weathering processes of a variety of geologic formations in the basin add salts, minerals, radionuclides, and trace elements to the surface and ground waters. Interbasin water transfers along the Continental Divide decrease the quantity of water in the headwater streams and the dilution capability of these streams. Water quality in the headwater streams along the Colorado Mineral Belt is being degraded by past mining activities that affect aquatic life. Urbanization and recreational activities are increasing throughout the basin and have a marked effect on the quantity of water needed as well as the quality. In the lower part of the basin, agriculture has a major effect on the quality of surface and ground waters predominantly because of return flows from irrigation.

\section{REFERENCES CITED}

Ackerman, D.J., and Brooks, Tom, 1986, Reconnaissance of ground-water resources in the North Fork Gunnison River Basin, southwestern Colorado: U.S. Geological Survey Water-Resources Investigations Report $85-4230,21$ p.

Apley, Martyn, 1982, Powderhorn surface water quality study: Gunnison, Colorado Western State College, $46 \mathrm{p}$. 
Bauch, N..J., and Apodaca, L.E., 1995, Bibliography, indices, and data sources of water-related studies, Upper Colorado River Basin, Colorado and Utah, 1872-1995: U.S. Geological Survey Open-File Report 95-450, $282 \mathrm{p}$.

Behnke, R.J., and Benson, D.E., 1980, Endangered and threatened fishes of the Upper Colorado River Basin: Fort Collins, Cooperative Extension Service, Colorado State University, Bulletin 503A, 34 p.

Benci, J.F., and McKee, T.B., 1977, Colorado monthly temperature and precipitation summary for period 1951-1970: Fort Collins, Colorado State University, Climatology Report 77-1, $300 \mathrm{p}$.

Britton, L.J., and Wentz, D.A., 1980, Water-quality characteristics of selected lakes and reservoirs in Colorado: U.S. Geological Survey Water-Resources Investigations Open-File Report 80-436, 139 p.

Bureau of Census, 1990, 1992, 1990-1992 census of population and housing: Washington, D.C., data on CD-ROM.

Butler, D.L., Krueger, R.P., Osmundson, B.C., Thompson, A.L., and McCall, S.K., 1991, Reconnaissance investigation of water quality, bottom sediment, and biota associated with irrigation drainage in the Gunnison and Uncompahgre River Basins and at Sweitzer Lake, westcentral Colorado, 1988-89: U.S. Geological Survey Water-Resources Investigations Report 91-4103, 99 p.

Cashion, W.B., comp., 1973, Geologic and structure map of the Grand Junction Quadrangle, Colorado and Utah: U.S. Geological Survey Miscellaneous Investigations Series Map I-736, scale 1:250,000.

Chaney, T.H., Kuhn, Gerhard, Brooks, Tom, and others, 1987, Hydrology of Area 58, northern Great Plains and Rocky Mountain coal provinces, Colorado and Utah: U.S. Geological Survey Water-Resources Investigations Open-File Report 85-479, 103 p.

Colorado Climate Center, 1984, Colorado average annual precipitation 1951 to 1980: Fort Collins, Colorado Climate Center, scale 1:500,000.

Colorado Department of Health, 1976, Report on the investigation of the water quality of the Colorado River, Dotsero, Colorado to Utah border: Denver, Colorado Department of Health, Water Quality Control Division, $17 \mathrm{p}$.

1992, Water quality in Colorado 1992: Denver, Colorado Water Quality Control Division, 103 p.

Colorado Division of Local Governments, 1994, Colorado population projections model database: Denver, Colorado, Demography Section, p. III-C-2-a\&b.

Colorado Water Quality Control Division, 1989, Colorado nonpoint assessment report: Denver, Colorado, $189 \mathrm{p}$.
Dennehy, K.F., Litke, D.W., Tate, C.M., and Heiny, J.S., 1993, South Platte River Basin-Colorado, Nebraska, and Wyoming: Water Resources Bulletin, v. 29, no. 4, p. 647-683.

Driver, N.E., 1994, National Water-Quality Assessment Program-Upper Colorado River Basin [water fact sheet]: U.S. Geological Survey Open-File Report 94-102, 2 p.

Everhart, W.H., and Seaman, W.R., 1971, Fishes of Colorado: Colorado Game, Fish, and Parks, 75 p.

Federal Water Pollution Control Administration, 1968, Biological studies of selected reaches and tributaries of the Colorado River: Federal Water Pollution Control Administration Report PR-15, $166 \mathrm{p}$.

Gallant, A.L., Whittier, T.R., Larsen, D.P., Omernick, J.M., and Hughes, R.M., 1989, Regionalization as a tool for managing environmental resources: U.S. Environmental Protection Agency Report EPA/600/3-89/060, $152 \mathrm{p}$.

Geldon, A.L., 1989, Hydrogeology of the Leadville Limestone and other Paleozoic rocks in northwestern Colorado, with results of the aquifer tests at Glenwood Springs: U.S. Geological Survey Water-Resources Investigations Report 87-4195, $96 \mathrm{p}$.

Heil, R.D., Romine, D.S., Moreland, D.C., Dansdill, R.K., Montgomery, R.H., and Cipra, J.E., 1977, Soils of Colorado: Fort Collins, Colorado State University Experiment Station Bulletin 566S, $39 \mathrm{p}$.

Hunt, C.B., 1974, Natural regions of the United States and Canada: San Francisco, W.H. Freeman and Company, $725 \mathrm{p}$.

Leahy, P.P., Rosenshein, J.S., and Knopman, D.S., 1990, Implementation plan for the National Water-Quality Assessment Program: U.S. Geological Survey OpenFile Report 90-174, 10 p.

Liebermann, T.D., Mueller, D.K., Kircher, J.E., and Choquette, A.F., 1989, Characteristics and trends of streamflow and dissolved solids in the Upper Colorado River Basin, Arizona, Colorado, New Mexico, Utah, and Wyoming: U.S. Geological Survey Water-Supply Paper 2358, $64 \mathrm{p}$.

Marschner, F.J., 1967, Major land uses of the United States, adapted from U.S. Department of Agriculture: National Atlas of the United States, p. 158-159, scale 1:7,500,000.

McLean, J.S., and Johnson, A.I., 1988, Regional aquifers systems of the United States-Aquifers of the western mountain area: American Water Resources Association Monograph Series 14, 229 p.

Natural Energy Resources Company, 1987, Report on fish, wildlife, and botanical resources: Denver, Colo., Natural Energy Resources Company, Appendix El Report on water use and quality, variously paged. 
Northwest Colorado Council of Governments, 1989 , Areawide water-quality management plan for Eagle, Grand, Jackson, Pitkin, Routt, and Summit Counties, Colorado, volume I: Northwest Colorado Council of Governments, variously paged.

Pearl, R.H., 1974, Geology of ground-water resources in Colorado-An introduction: Colorado Geological Survey Special Publication 4, $47 \mathrm{p}$.

Romberger, S.B., 1980, Metallic mineral resources of Colorado, in Kent, H.C., and Porter, K.W., eds., Colorado geology: Denver, Rocky Mountain Association of Geologists, p. 225-236.

Schruben, P.G., Amdt, R.E., and Bawlec, W.J., 1974, Geology of the conterminous United States at $1: 2,500,000$ $\rightarrow$ digital representation of the 1974 P.B. King and H.M. Beikman map: U.S. Geological Survey Digital data series, DDS-11, on CD-ROM.

Spears, C.F., and Kleven, E.V., 1978, Soil survey of Mesa County, Colorado: Washington, D.C., U.S. Soil Conservation Service, $58 \mathrm{p}$.

Taylor, O.J., Hood, J.W., and Zimmerman, E.A., 1986, Hydrogeologic framework of the Upper Colorado River Basin-Excluding the San Juan BasinColorado, Utah, Wyoming, and Arizona: U.S. Geological Survey Hydrologic Atlas HA-687, scale $1: 3,000,000$.

Tweto, Ogden, comp., 1976, Geologic map of the Craig $1^{\circ}$ by $2^{\circ}$ quadrangle, northwestern Colorado:

U.S. Geological Survey Miscellaneous Investigations Series Map I-972, scale 1:250,000.

Tweto, Ogden, comp., 1979, Geologic map of Colorado: U.S. Geological Survey State Geologic Map, scale 1:500,000 (reprinted).

Tweto, Ogden, 1980, Tectonic history of Colorado, in Kent, H.C., and Porter, K.W., eds., Colorado geology: Denver, Rocky Mountain Association of Geologists, p. 5-9.

Tweto, Ogden, Moench, R.H., and Reed, J.C., Jr., 1978, Geologic map of the Leadville $1^{\circ}$ by $2^{\circ}$ quadrangle, northeastern Colorado: U.S. Geological Survey Miscellaneous Investigations Series Map I-999, scale $1: 250,000$.

Ugland, R.C., Cochran, B.J., Hiner, M.M., and Wilson, E.A., 1994, Water resources data Colorado, water year 1993 -v. 2, Colorado River Basin: U.S. Geological Survey Water-Data Report CO-93-2, 394 p.

Upper Colorado River Commission, 1993, Forty-fifth annual report of the Upper Colorado River CommissionSeptember 10, 1993: Salt Lake City, Utah, 99 p.

U.S. Department of the Interior, 1993, Quality of water Colorado River Basin-Progress report no. 16: U.S. Department of Interior, $73 \mathrm{p}$.
U.S. Environmental Protection Agency, 1987, Ambient water quality criteria for selenium-1987: Washington, D.C., U.S. Environmental Protection Agency, 39 p.

U.S. Geological Survey, 1985, National Water Summary 1984 -Hydrologic events, selected water-quality trends, and ground-water resources: U.S. Geological Survey Water-Supply Paper 2275, 467 p.

U.S. Geological Survey, 1988, National Water Summary 1986-Hydrologic events and ground-water quality: U.S. Geological Survey Water-Supply Paper 2325, $560 \mathrm{p}$.

Ward, J.V., and Kondratieff, B.C., 1992, An illustrated guide to the mountain stream insects of Colorado: Niwot, Colo., University Press of Colorado, $191 \mathrm{p}$.

Ward, J.V., Zimmerman, H.J., and Cline, L.D., 1986, Lotic zoobenthos of the Colorado System in Davies, B.R., and Walker, K.F. eds., The ecology of river systems: Boston, DRW Junk Publishers, p. 403-423.

Warner, J.W., Heimes, F.J., and Middelburg, R.F., 1985, Ground-water contribution to the salinity of the Upper Colorado River Basin: U.S. Geological Survey WaterResources Investigations Report 84-4198, 113 p.

Wentz, D.A., 1974, Effect of mine drainage on the quality of streams in Colorado, 1971-72: Water Conservation Board, Water Resources Circular 21, 117 p.

Wilson, W.W., 1965, Pumping tests in Colorado: Colorado Water Conservation Board, Ground-water Series, Circular 11, $361 \mathrm{p}$.

Woodling, John, 1985, Colorado's little fish-A guide to minnows and other lesser known fishes in the State of Colorado: Denver, Colorado Division of Wildlife, $77 \mathrm{p}$.

Wright, W.G., and Butler, D.L., 1993, Distribution and mobilization of dissolved selenium in ground water of the irrigated Grand and Uncompahgre Valleys, western Colorado: Park City, Utah, Management of Irrigated and Drainage System, p. 770-777. 